\title{
Knowledge Mobilization and Mental Health Policy: Lessons from the Canadian Consensus Conference on the Mental Health of Emerging Adults
}

[French translation: Mobilisation des connaissances et politiques de santé mentale]

\author{
Gillian Mulvale and Christina Roussakis \\ McMaster University \\ Christopher Canning, Despina Papadodoulos, and Francine Knoops \\ Mental Health Commission of Canada
}

[La version française suit.]

\begin{abstract}
This case study explores how the Consensus Conference on the Mental Health of Emerging Adults, hosted by the Mental Health Commission of Canada in 2015, can impact mental health policy and practice in Canada. The study draws on interviews from 14 delegates who attended the conference. Participants praised innovations such as the inclusion of an emerging adult panel that provided feedback on all discussions, and efforts to make the consensus-building process meaningful in the Canadian policy context. Findings suggest that consensus conferences are a promising way to operationalize the Mental Health Strategy for Canada through policy and practice changes.
\end{abstract}

Key words: mental health policy, knowledge translation, emerging adults, mental health, consensus conference, policy context, capacity development

Gillian Mulvale, DeGroote School of Business, McMaster University, Hamilton, Ontario; Christina Roussakis, DeGroote School of Business, McMaster University, Hamilton, Ontario; Christopher Canning, Mental Health Commission of Canada, Ottawa, Ontario; Despina Papadodoulos, Mental Health Commission of Canada, Ottawa, Ontario; Francine Knoops, Mental Health Commission of Canada, Ottawa, Ontario.

The authors would like to acknowledge the informants for their excellent input and insights to this research.

Correspondence concerning this article should be addressed to Gillian Mulvale, DeGroote School of Business, McMaster University, Ron Joyce Centre, 4350 South Service Road, Burlington, ON L7L 5R8; phone (905) 525-9140 ext. 28190; mobile (289) 983-0741. Email: mulvale@mcmaster.ca 


\section{RÉSUMÉ}

Cette étude de cas examine comment la Conférence consensuelle sur la santé mentale des adultes émergents, tenue par la Commission de la santé mentale du Canada en 2015, peut avoir une incidence sur les politiques et les pratiques de santé mentale au Canada. Elle se fonde sur des entrevues menées auprès de 14 délégués et déléguées ayant participé à la conférence. Les participants et participantes ont fait l'éloge d'innovations comme l'inclusion d'un panel d'adultes émergents fournissant leurs commentaires sur toutes les discussions ainsi que les efforts consentis pour rendre le processus d'établissement de consensus aussi pertinent que possible dans le contexte politique canadien. Les résultats révèlent que les conférences consensuelles sont un moyen prometteur de mettre en application la Stratégie en matière de santé mentale pour le Canada grâce aux changements qu'elles permettent au niveau tant des politiques que des pratiques.

Mots clés : politique de santé mentale, application des connaissances, adultes émergents, santé mentale, conférence consensuelle, contexte politique, développement des capacités

\section{BACKGROUND}

Transition-aged youth, herein referred to as emerging adults (EAs), are a priority population that requires greater understanding, unique service delivery, and health policy approaches, particularly during the transition from child and youth to adult mental health and addiction as described in Changing Directions, Changing Lives: The Mental Health Strategy for Canada (the Strategy; Mental Health Commission of Canada, 2012). The term "emerging adult" is increasingly used in the mental health field to describe the various age ranges of youth and young adults between 16 to 25, who are going through significant social, intellectual, psychological, and neurological growth and development toward adulthood (Arnett, 2000). The term "emerging" acknowledges this phase of life as a dynamic process, rather than a prescribed span of time driven by chronological age. In some literature, emerging adulthood includes youth up to the age of 29 and as young as 14. International and Canadian literature has pointed to particular challenges for this age group, but action to date has been incremental (Davidson \& Cappelli, 2011; Di Rezze et al., 2016; Embrett, Randall, Longo, Nguyen, \& Mulvale, 2016; McGorry, 2007; Mulvale et al., 2016; Singh et al., 2010). Although a number of new initiatives are underway at the national and local levels in Canada, the Mental Health Commission of Canada (MHCC) felt that more needed to be done.

In September 2015 and in partnership with the Children's Hospital of Eastern Ontario, the MHCC released Taking the Next Step Forward: Building A Responsive Mental Health and Addictions System for Emerging Adults (Taking the Next Step; Mental Health Commission of Canada, 2015c), which provides a detailed scan and analysis of current policies and practices that pertain to EAs transitioning from child and youth to adult mental health and addiction services. Subsequent to that report, the MHCC sponsored and organized a consensus conference held in November 2015, entitled The Mental Health of Emerging Adults: Making Transitions a Priority in Canada (the Conference). The Conference adopted Taking the Next Step as a foundational document, along with other evidence from the literature and expert testimony, to frame the policy questions, speaker presentations, and discussions. There were 200 participants at the event from all provinces and territories with the exception of Nunavut. Participants included EAs, family caregivers, 
provincial, territorial, and federal policy makers, researchers, mental health organization representatives, and clinicians.

The term consensus conference refers to a structured meeting whose purpose is to "define levels of agreement on controversial subjects..." (Fink, Kosecoff, Chassin, \& Brook, 1984), using an approach that has been used in many settings since 1977 (Jacoby, 1988), and most notably by the National Institutes of Health $(\mathrm{NIH})$ in the United States to evaluate healthcare technologies and biomedical research products (Fink et al., 1984). The NIH consensus conferences generated consensus statements on existing research to develop guidelines for clinical practice. In Canada, the Society of Obstetricians and Gynecologists of Canada has used this approach for clinical guidelines (Lomas et al., 1988), and more recently, the Institute of Health Economics in Alberta has conducted a number of consensus conferences to advance recommendations for policy development (Institute of Health Economics, 2016).

Typically, five to six questions are posed in advance of the event for a panel (or jury) to consider in response to presentations of empirical evidence. These questions set the scope and direction of discussions during the conference. The panel draws on the evidence during its deliberations to develop a consensus statement that is presented for discussion and endorsement on the last day of the conference before being widely disseminated (Jacoby, 1988). Some final editing to the consensus statement may follow the conference.

The MHCC made some modifications to this basic format for its own Conference. Leading up to the event, two advisory groups - a panel of EAs (the EA Innovators) and a group of leading experts and policy makers in mental health-helped to co-design the Conference format, themes, and outcomes. The EA Innovators and delegates also gave input during the event, which is not typical of the consensus conference format. The Conference was anchored by evidence presentations from 12 speakers who then addressed specific questions developed by the advisory groups. Each presentation was structured under one of four interrelated policy themes. ${ }^{1}$ Following each block of thematic presentations, the 16 person jury, EA Innovators, and conference delegates asked questions of the speakers. While the jury and EA Innovators deliberated on each theme, delegates shared their perspectives at their tables, with group feedback captured by facilitators and individuals' feedback recorded in writing and provided directly to the jury and EA Innovators. On the final morning of the Conference, the jury presented its draft consensus statement to delegates for group and plenary discussion. The jury and EA Innovators considered the oral and written input from delegates in the months following the Conference as they finalized the consensus statement. ${ }^{2}$

Such consensus conferences are a specific type of policy dialogue (Lavis, Boyko, Oxman, Lewin, \& Fretheim, 2009). Dialogue success depends on having appropriate meeting environments, a mix of participants, and use of evidence (Boyko, Lavis, Abelson, Dobbins, \& Carter, 2012). An appropriate environment requires skilled facilitation, pre-defined expectations for "consensus," and identification of clear and specific recommendations (Fink et al., 1984). Participants should be able to represent their constituencies, implement findings, or be recognized as experts, which includes lived experience. Evidence should be available on the subject area and be used as a basis to carefully define the issues to be discussed (Fink et al., 1984; McGlynn, Kosecoff, \& Brook, 1990; Murphy et al., 1998). What sets a consensus conference apart from most policy dialogues is the emphasis placed on trying to achieve a level of consensus among participants even if this is not always realized in practice (Lavis et al., 2009). There is an implicit intention that consensus conferences can provide "official" approval to recommendations because they reflect evidence and have the input of a 
respected and credible jury panel (Lomas et al., 1988, p. 3004). The consensus conference approach has the potential to broaden and qualify public debate, influence policy making or political decision making, and introduce participatory procedures into decision making (Nielsen et al., 2006).

As Murphy (1998) and colleagues indicate, there is a temptation to judge consensus conferences as most successful if they produce "results that are not only correct but also influential," (p. 22) yet the legitimacy given to public participation and deliberative approaches in decision making may vary by jurisdiction (Nielsen et al., 2006). Even when consensus conferences result in limited direct policy influence, they may serve a useful educational purpose that can support implementation and action at the local level (Kosecoff et al., 1987). Lomas and Brown (2009) suggest that in the policy-making world, consensus conferences play a more important role in influencing new concepts and ways of thinking, which can be amplified by involving both expert and non-expert public input (Lomas et al., 1988; Nielsen et al., 2006).

For the MHCC, a national organization in a federation where the primary responsibility for healthcare delivery resides with the provinces and territories, it is important to understand whether the consensus conference approach can facilitate uptake and the spread of evidence into both policy and service delivery. Using the Conference as a qualitative case study, our objective was to understand to what extent and in what ways consensus conferences can influence mental health policy and practice in Canada. We sought to explore delegates' perspectives about how attending the Conference influenced their capacities to undertake evidence-informed practice and policy, the helpfulness of this approach in the Canadian context, and any influence of the Conference on their subsequent activities. By exploring the lessons learned from this case study, we argue that consensus conferences are important vehicles for knowledge mobilization, and offer a unique opportunity for stakeholders to better align mental health policy and service delivery with available evidence, and in so doing, assist in the mobilization and implementation of Strategy recommendations.

\section{METHODS}

Using the Conference as a particular case, this qualitative case study (Yin, 2003) examines consensus conferences as vehicles for knowledge mobilization and for building individual and organizational capacities to influence mental health policy and practice in Canada. A key strength of case studies is their ability to identify lessons learned that can be used to improve practices in other settings (Lincoln \& Guba, 1985). Consistent with the case study approach of using a priori theory to improve rigour (Harrison, 2001; Yin, 2003), we adopted the Boyko et al. (2012) conceptual model of dialogue features and intended capacity impacts as a guiding conceptual framework for the research. The model suggests that individual capacities can be strengthened in the short term by enhancing mutual understanding, fostering new relationships, improving communication skills, boosting confidence and sense of empowerment, and introducing alternative ways of thinking about policy problems and solutions. The model also suggests that over the medium term, these individual capacities can lead to greater organizational capacities to influence policy agendas, formulate and take action when policy windows open (Howlett, Ramesh, \& Perl, 2009). Over the longer term, system level capacities for evidence-informed policy making may also be enhanced. In this study, which focuses on data gathered in the nine months since the Conference was held, we expect primarily short-term effects to be discussed. 
Telephone interviews lasting 30 to 45 minutes were held with 14 purposefully sampled Conference delegates between May and August, 2016. Table 1 lists the sampling frame by participant type, which was designed to capture a diversity of perspectives (EA, family member of EA, service provider, policy maker), ${ }^{3}$ delegate types (EA innovator, jury member, advisory group member, speaker, general delegate) ${ }^{4}$ and sectors (health, education, mental health, justice, child welfare), ${ }^{5}$ as well as geographic and cultural diversity. The semi-structured interview guide contained questions about participants' perspectives regarding what they learned at the Conference, relevant activities undertaken since the event, and policy considerations. Interviews were recorded and transcribed by professional transcriptionists. Coding followed a deductive approach, beginning with themes derived from the Boyko et al. (2012) framework and supplemented by emergent themes (Miles, Huberman, \& Saldana, 2013). The researchers coded and analyzed all transcripts using NVivo 10 qualitative software. Initially, two researchers independently coded a selection of interview content and found a very high level of concurrence. Any discrepancies were discussed until consensus was reached. The resulting codebook was used in coding all interviews. To enhance rigour, analysis of interview findings was triangulated with documentary evidence (Schwandt, 2007; Yin, 2003) from three sources: (i) written summaries of three post-Conference telephone debriefing meetings held post-conference with jury members, EA Innovators, and advisory group members, (ii) delegates' responses to survey questions on Conference evaluation forms ( $n=97$; Mental Health Commission of Canada, 2015a), and (iii) notes taken at the Conference by an outside consultant (Mental Health Commission of Canada, 2015b). We briefly summarize the survey feedback, and predominantly focus on what was heard in the key informant interviews because of the close alignment of findings across data sources. We then discuss lessons learned based on participant feedback and reflections of the consensus conference organizers.

Table 1

Sampling Frame

\begin{tabular}{lc}
\hline Participant Type: & Number \\
\hline EA Innovator & 2 \\
Family Members of EAs (1 advisory group member, 1 jury member) & 2 \\
Jury Members (selected by sector health, education, mental health, justice, child welfare, etc. from & 4 \\
across Canada) & 4 \\
Delegates: & \\
$\quad$ Policy Maker (1) & \\
Advisory Group Member (1) & \\
Speaker (1) Other general delegate (1) & 2 \\
MHCC Staff (1 policy analyst, 1 program manager) & 14 \\
Total & \\
\hline
\end{tabular}




\section{FINDINGS}

Three main themes emerged from the data: feedback on the Conference processes and features, enhanced capacities for use of evidence in policy making, and influence on policy making since the event. We use these themes to organize our presentation of the findings.

\section{Conference Processes and Features}

Generally, informants commented favourably on the Conference in the post-event evaluation survey (see Figure 1), with $86 \%$ of participants reporting being satisfied or very satisfied with respect to their overall experience of the event, and $70 \%$ reporting satisfaction with dialogue and networking opportunities. Topics scoring lower satisfaction were described as having enough information to prepare for the conference, and clarity about conference objectives ( $57 \%$ and 59\% satisfaction respectively).

The survey comments suggest overall satisfaction with respect to the meeting environment, mix of participants, and use of evidence. One respondent described the Conference as "structured and organized very well" [GD2], although suggestions for improvement were noted (see Table 2, column 1). The two and a half days" length was described as appropriate for the agenda, but also "quite intense" [AG3] according to some participants who felt it could have been lengthened to "a full three days" [EA1]. Pre-meeting preparation was considered "very thorough" and "very helpful" by many informants [EA1], however one family member on the jury did not feel adequately prepared "coming into that arena with people who are much more experienced" [FM1JM].

(Continued on page 9)

Figure 1

Satisfaction with Conference Preparation, Objectives, Dialogue, and Experience

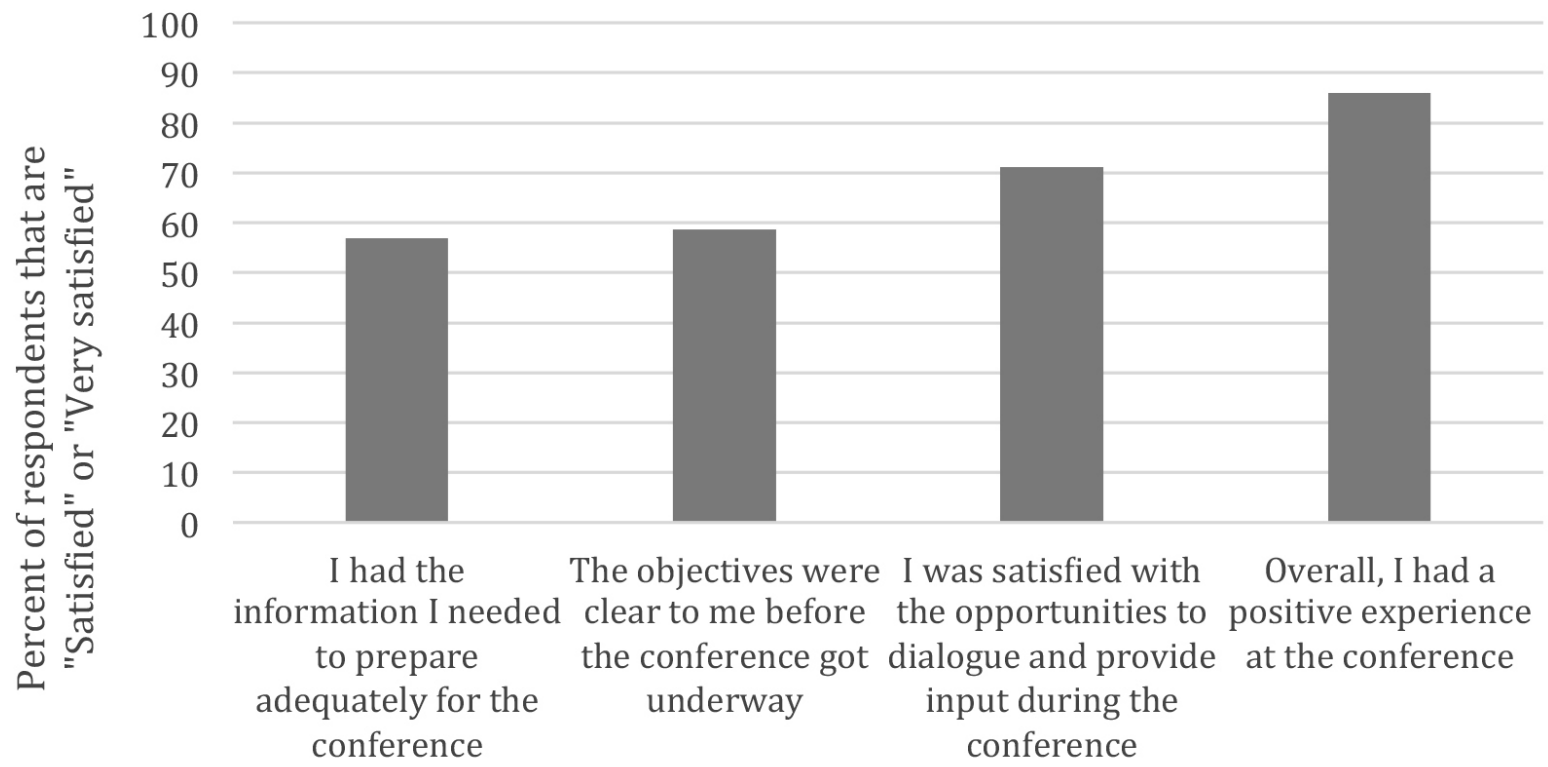




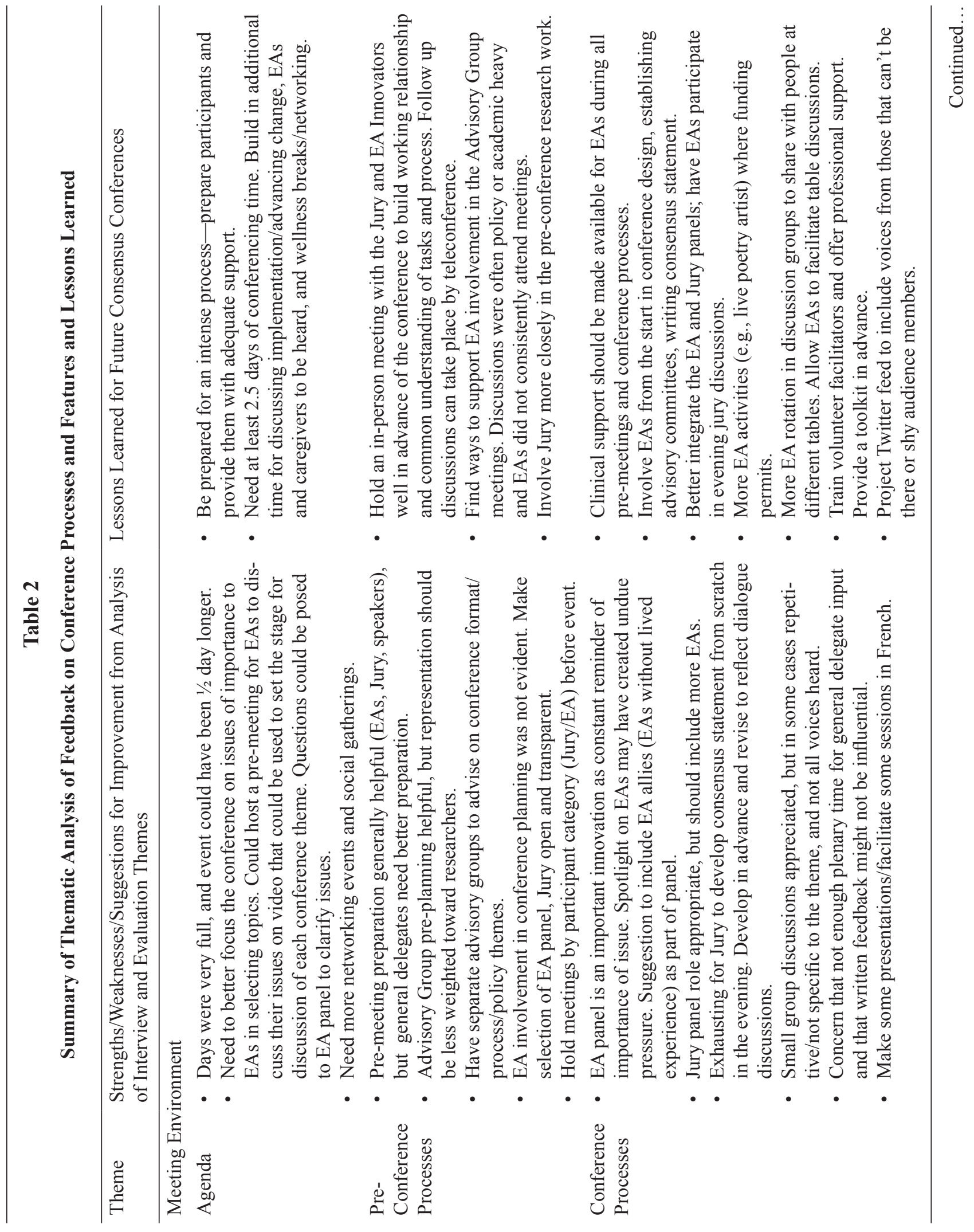



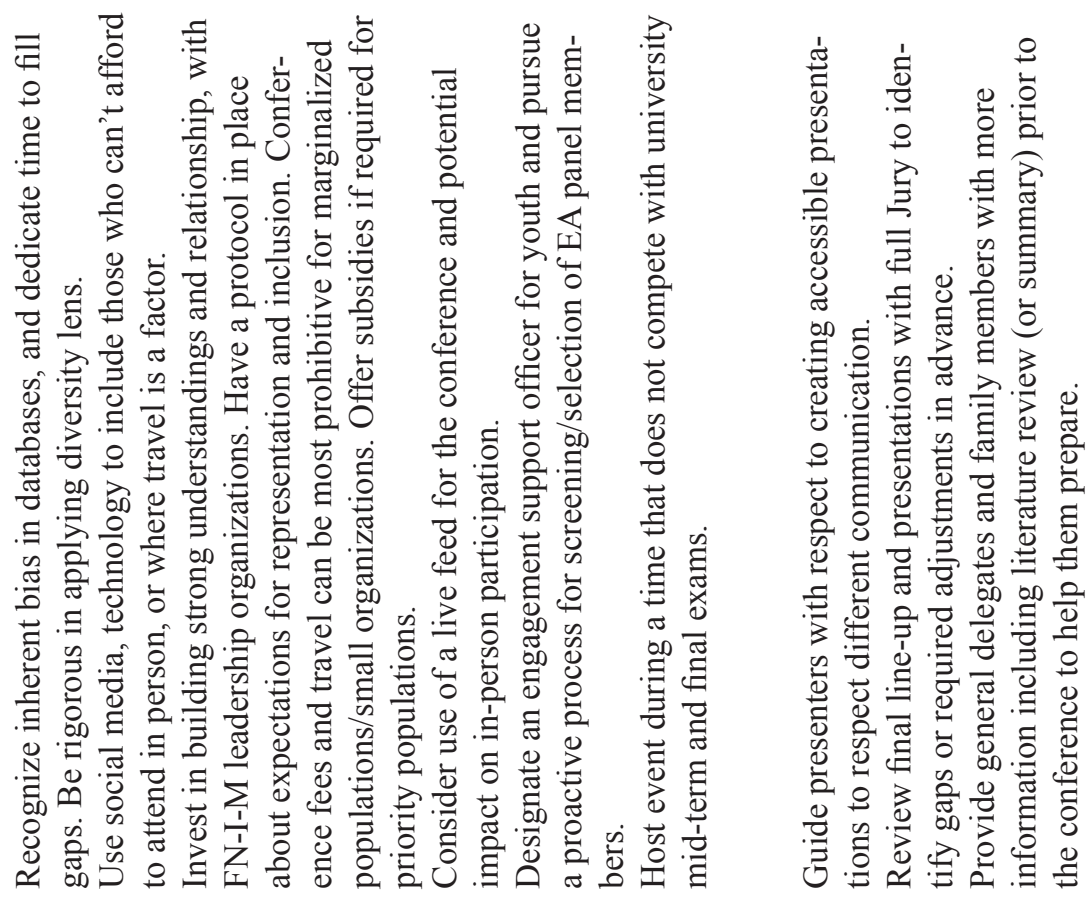

อั

学

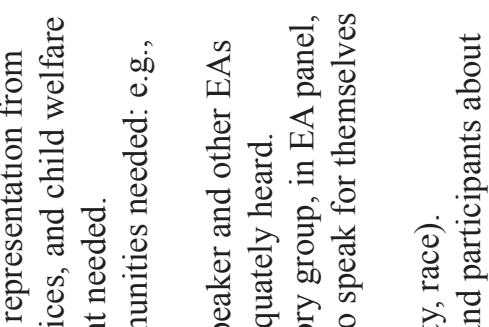

.

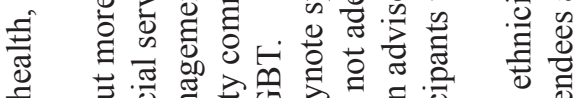

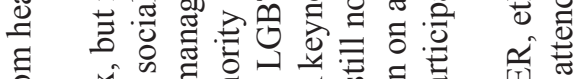

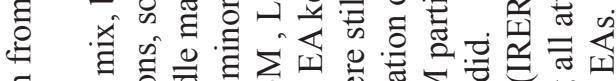

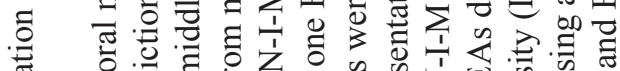

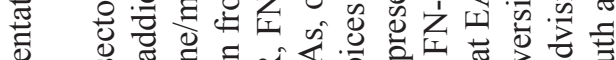

क

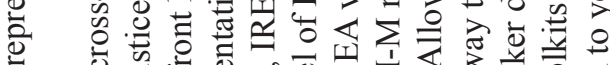

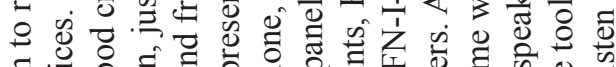

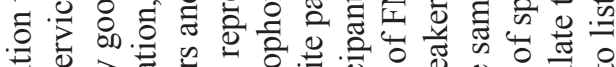

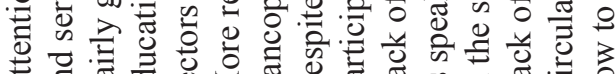

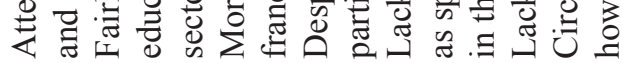

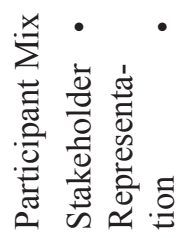




\section{(Continued from page 6...)}

The roles of the advisory group, the Jury panel, and the EA Innovators panel were considered to be appropriate by most informants. The EA panel was described as an "innovative" feature [GD4] that served as a "constant reminder" that "this is the group we're talking about, this is who we're here to serve" [JM2]. At the same time, respondents expressed concern that the constant spotlight placed on EAs may have created undue pressure, and that more clinical support was needed. Several suggestions were made to make the Conference more EA centric, with greater EA involvement in Conference design, as speakers, Jury members, and in drafting the consensus statement (Mental Health Commission of Canada, 2015a). Greater interface between the EA panel and the Jury panel was also called for. Jury members suggested that mock content for the consensus statement could be developed in advance and honed by the Jury to reflect dialogue discussions. Writing the consensus statement from scratch was described as "very exhausting" following long days of meetings [JM1SP]. In this regard, the support from MHCC staff and writers was described as "very helpful and necessary" [JM1SP].

The processes for gathering input from general delegates throughout the Conference were generally well received. Some informants suggested that at future events, delegates could benefit from greater preparation for the table discussions, such as toolkits to enhance their skills in listening and checking in with EAs and families (Mental Health Commission of Canada, 2015a).

In terms of participant mix, many felt that the conference was representative. One EA stated "[the Conference] encompassed a lot of the people and stakeholders that are championing transition age mental health across Canada" [EA1]. Some informants felt there could have been better representation from the education, justice, addictions, social services, and child welfare sectors, from program and front line managers, and certain populations. For example, one delegate suggested that if some sessions had been conducted in French, there might have been better representation from francophone Canadians outside Ontario. Others thought that First Nations, Inuit, and Métis (FN-I-M) and immigrant, refugee, ethnic, and racialized groups (IRER) were underrepresented.

Although there was FN-I-M representation on the Jury and among conference delegates, some participants expressed legitimate concerns about the lack of prior engagement with Indigenous groups and delegates. The result was that the consensus statement recommendations did not speak adequately to the realities and urgent needs of FN-I-M populations. While continuing to work with the Jury and EA Innovators on the consensus statement following the conference, the MHCC met with FN-I-M members of the Jury and youth representatives from the Assembly of First Nations (AFN), Métis National Council (MNC) and Métis Nation, and Inuit Tapiriit Kanatami (ITK) to determine how to appropriately and adequately address the mental wellness needs of FN-I-M EAs in the final consensus statement, and to facilitate knowledge sharing. These meetings enhanced relationships with FN-I-M leaders and stakeholders.

Opinions varied about effectiveness of research evidence presented at the Conference. Some informants found it "was encouraging to see what is already working in terms of transition age mental health" [EA1], and thought the evidence was appropriately comprehensive [GD2]. However, one advisory group member thought that the research presentations were difficult for many youth and family members to understand, which limited delegates' abilities to arrive at clear decisions [AG1]. One family member in the Jury felt that not enough evidence was presented on the role of family members in EA mental health, but that this may 
reflect data limitations [FM1JM]. The four themes used to organize the conference discussions at the event were generally viewed as appropriate, complementary, and important to include, but that more attention should have been given to issues of diversity and equity for marginalized EA groups.

\section{Influence on Capacity for Evidence-Informed Policy and Programming}

Interview informants pointed to a number of ways in which participating in the Conference strengthened their individual capacities to improve the mental health of EAs, which are summarized in Table 3). Consistent with the Boyko model, informants described how discussions at the Conference enhanced mutual understanding, particularly with respect to EA perspectives. As one Conference speaker stated: "there's no greater expert than people who have repeatedly been through the system" [GD2]. As this EA explained, "when it comes to something like policy ... in mental health, I've never really heard of EAs and youth being a part of that... It was really nice to see that being valued" [EA2]. Gaining insight into EA perspectives was described as essential because too often people are:

... taking care of their own slice of their own job, but they don't see it from that perspective of somebody who's trying to navigate ... not knowing where to go or how-knowing that their options are limited, and the best they can do maybe is show up at the ER again. [GD2]

Active involvement of EAs at so many levels of the Conference also inspired adoption of a national perspective to address the unique needs of different people in Canada, including minority groups, such as Indigenous peoples [GD4] because "... we need to understand all the sectors, all the segments of our society, and their mental health. It builds a personal capacity ... for empathy and responsiveness" [GD3]. Other informants felt that the Conference provided a view of the broader landscape, particularly "the different perspectives from across the country and through the professions that were represented" [JM1SP].

Several informants explained that capacities were also enhanced through forging new relationships among EAs, service providers, family members and researchers. One EA felt that “... by the end of the Consensus Conference, after two and a half days, a lot of connection and a lot of communication and rapport was built..." [EA1]. Even experts and policy makers, who were already well connected at the national level, described benefits from new relationships at the provincial and local levels, and hearing about community initiatives [GD1]. Delegates' capacities were also enhanced through new ways of thinking about mental health during emerging adulthood. One delegate came to realize that the needs of EAs are not static and that ongoing capacity development will be required to stay abreast of the landscape of young adults and their mental health because of social and technological changes. [GD3]

For EAs and family members, the Conference provided specific capacities with respect to understanding policy-making processes and what is needed to effect change in policy content. One EA described learning how to "... very eloquently hone down what needs to happen in order for transition age emerging adults' mental health to be a priority...." [EA1] and another explained that:

In order to form or change ... a policy, you need people to sit down at a table and listen, eyeball to eyeball, face to face, and dialogue. You can do this better than academic journals. You can do this better than presentations passively received [by] recipients. But I think the thorny and fluid constructs of mental health can best be tackled or understood, and the policy can be changed by forums like [the Conference]. [EA2]

(Continued on page 12) 


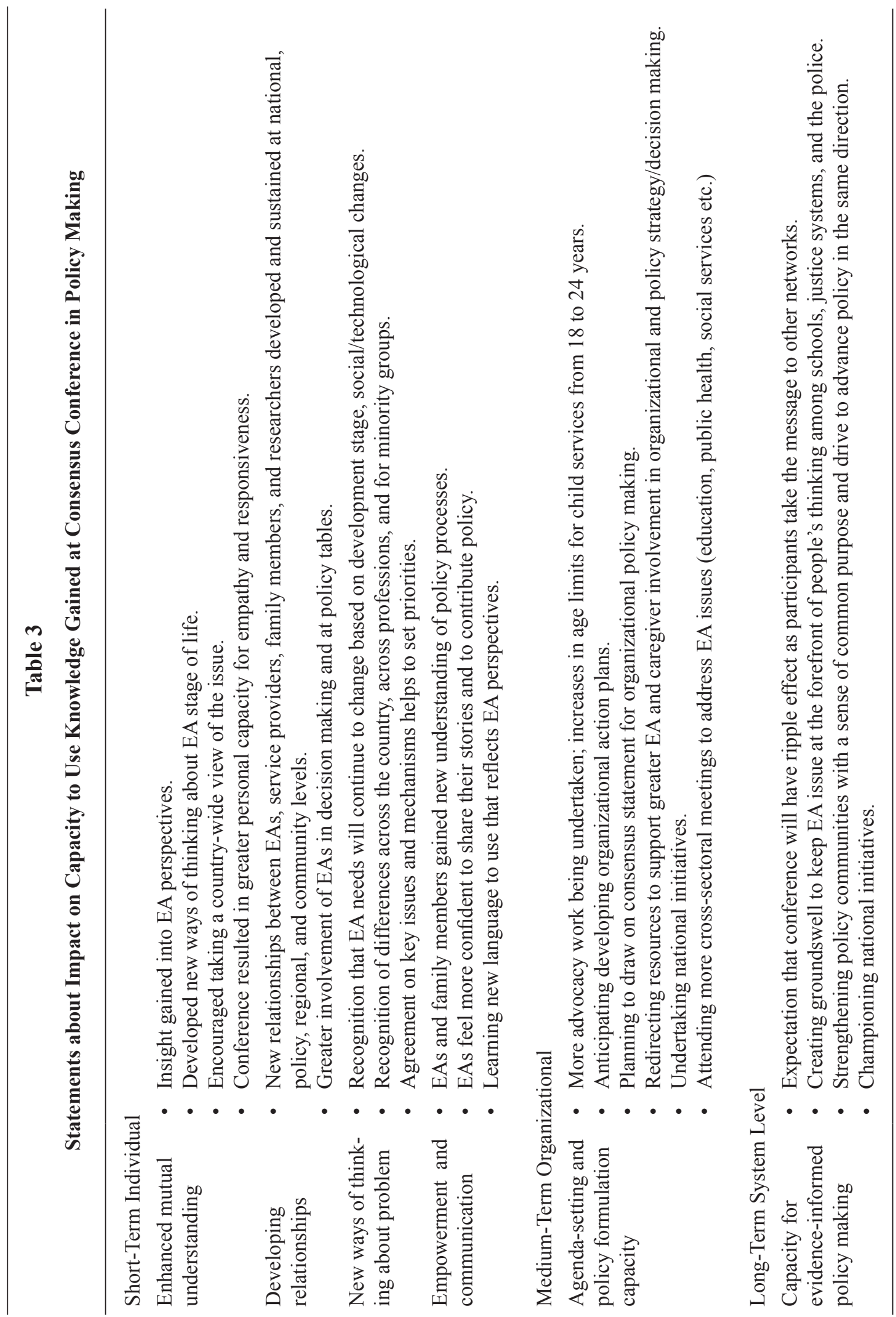




\section{(Continued from page 10)}

Through the dialogue process, participants also began to set priorities for action. As one EA explained: "consensus conferences are great for addressing the topic in a more general way ... and then finding exactly which topics within it need to be discussed" [EA2]. This narrowing of topics results from having people “... from diverse areas and working on different aspects of the issue ... come together and make a very concerted effort to agree on ... the key issues and ... mechanisms for moving policy around those issues" [GD2]. Other informants described feeling more empowered to influence policy following the Conference, whether that be as an EA having greater confidence to share his or her story and "... contribute to ... recommendations in policy" [EA2], or as this jury member explained, being able to draw on a common understanding and language:

I have an added confidence, not just coming from my own soapbox, or perspective, but rather from this broader perspective where things have been validated, some of my learning has advanced, shifted. Some new terminologies, particularly coming from the emerging adults themselves that is useful in conversation. Those are the things that I think have made a difference. [JM2]

Most informants did not directly discuss capacity development at the organizational or systems levels. This is not surprising given the relatively short time that had elapsed between the Conference and the interviews. Survey responses suggested that some delegates planned to do more advocacy work to raise age limits on child services from 18 to 24 years and to develop concrete organizational action plans. One Jury member informant anticipated using the final consensus statement as a basis for developing an organizational strategy to address mental health needs of EAs, and to "reach out to ... some of the emerging adults that spoke of this at the Conference, but certainly some local ones as well to help..." in doing so. [JM3].

At the systems level, Jury members saw the Conference as having a "ripple effect" as delegates take the messages from the Conference to others [JM2, JM3] as part of the knowledge exchange process. This can "advance the agenda" among organizations such as schools, the justice system, and the police, that have an interest in EA mental health [JM2]. The Conference was described as creating a "groundswell" that keeps the issue at the forefront of people's thinking [AC2SP] and that "... the more people that are actively engaged in the process, the greater the groundswell is to shift and create momentum" [JM1SP]. The Conference was described as strengthening policy communities by building a common understanding of the problem and proposed solutions, which can enable more effective advocacy as different groups forge a "sense of common purpose" for "policy advancement" [JM2]. An EA remarked that the Conference encourages different advocates "...to make a change in the same direction together" [EA2]. Similarly, groups that previously were on "different paths in their advocacy" were described as having found "a lot of synergy" to "bond and basically create that community ... from all across Canada" to "champion initiatives that are national in scope" [EA1].

\section{Expected Influence on Policy Making}

The Conference also was described as preparing people to take action when policy windows open by providing "... some evidence around: What do those involved in this arena believe? What do they see as the opportunity? That is evidence that can also advance public policy." [JM2] However, there were mixed feelings about the Conference recommendations. One advisory group member thought they were "concise and clear," providing "actionable ways to implement," them that would "resonate with different organizations and people across sectors" [AG3]. Another felt that there were "... a lot of solutions ... and a lot of testimonials 
that backed the recommendations up." [AG2]. However, several participants felt that there wasn't enough focus on how to make change happen [FM1], [AG2], (Mental Health Commission of Canada, 2015a). One advisory committee member described the outcome as a set of guiding principles rather than recommendations: "I think that at the end of the day they aren't terribly meaningful because they're not really connected to service. I think the principles are okay. They're not really recommendations" [AG2]. However, one Jury member thought that this would help because "... provinces, programs, individuals can actually find the space ... in the recommendations" to enable them to affect change at the local, provincial, or national level [JM1]. Another Jury member expected that the consensus statement, principles, and recommendations would be very influential in fundraising and in efforts to encourage more investment in the needs of EAs [JM3].

Many informants expected the Conference to improve policy content, recognizing that "policy change takes time" [AG3] and that it was "one important step along a path to increase knowledge" involving a lot of people over a number of years [JM2] that would need to continue. Informants also suggested important contextual factors such as the presence and activities of change champions [EA1] within organizations that "are receptive to these voices.... and feedback." [AG3] Not all organizations were seen to be ready to make change [JM1SP]. There were also calls for local and national leadership for sustained improvement [GD1], and to push for a common vision across the country, so that youth don't experience major disparities in service quality when they move from one community to another [JM3].

In the nine months since the Conference was held, informants ascribed a surprising number of actions to their participation in the event. Many service providers and EAs discussed continued networking with other participants, to learn from and support each other. "... even though most of us are far apart from each other physically" [EA2]. Others discussed undertaking more advocacy work, making more conference presentations, and working with different stakeholders on national initiatives [AG3]. One EA informant spoke about attending more cross-sectoral meetings after learning the importance of hearing multiple perspectives during the Conference discussions:

And I think ... the one thing that I took away from the Consensus Conference is how important it is to be a part of a decision-making table where there are so many representatives from different sectors. [EA2]

Other post-Conference actions taken include insisting that EAs be included at planning tables [GD2], making policy service integration recommendations to different provincial governments [AG3], and pushing organizations to increase the transition age requirement from 18 to 24 years to improve EAs readiness [JM1SP]. The need to move away from an age-based system was similarly described in the debriefing notes and the survey forms (Mental Health Commission of Canada, 2015a).

\section{DISCUSSION}

While it is too soon to formally evaluate the influence of the Conference on mental health policy making in Canada, the findings of this case study suggest that through the use of appropriate evidence, the right mix of participants, and innovations made to tailor the consensus conference format to the EA population and context, the MHCC was successful in hosting an event that enhanced delegates' capacities for evidenceinformed improvements to mental health policy and practice. Informants described feeling better able to integrate lessons from the Conference in their subsequent activities and reported early signs of influence on organizational policies. 
Informants described enhanced capacities to understand complex policy processes in support of advocacy efforts, (Gauvin, 2014; Howlett et al., 2009; Walt et al., 2008), gaining new ideas about emerging adulthood that can assist in problem definition and forging potential policy solutions (Campbell, 2002; Stone, 2001), and in clarifying priorities for action. The Conference also opened up thinking about how to engage EAs in local planning and decision making. The relationships that were built helped to strengthen policy communities and networks (Howlett et al., 2009; Sabatier, 1995), and informants anticipated that the release of the consensus statement would advance EA mental health agenda with a broad range of organizations beyond mental healthcare delivery.

In these ways the Conference helped to advance both interests and ideas within the Canadian institutional context, in a way that can support formulation of policy solutions according to the 3-i (interests, ideas, and institutions) framework of policy development (Gauvin, 2014; Walt et al., 2008). At the same time, by shining a light on the problem of EA mental health, the Conference helped to create a more conducive political context to spur the inclusion of the EA mental health issue on policy agendas. It helped to develop more consistent framing of policy problems by different stakeholders, which can enhance the development of more compelling problem definitions (Houston \& Richardson, 2000). Through the coupling of a recognized policy problem, with proposed solutions and political attention, the MHCC as convenor of the Conference has the potential to act as a "policy entrepreneur," opening a policy window to advance the issue of EA mental health onto government decision-making agendas, consistent with the "three-streams" model of agenda-setting (Kingdon, 1995). While some informants were concerned that the Conference recommendations were too broad, others viewed high-level principles as an inclusive strategy given the number of individuals and organizations with the potential to advance the agenda at many different levels of policy and practice in the Canadian institutional context.

While these findings suggest promise for longer-term influence on policy making, they also suggest ways to enhance consensus conferences as knowledge exchange mechanisms for mental health policy in Canada, as summarized in the second column of Table 2. Some informants suggested that there might have been room to cast a wider net of participants to hear different voices from other sectors and for greater FN-I-M involvement. While health, mental health, and post-secondary health services were well represented, other sectors (justice, the secondary education system, and child welfare) were less so. The MHCC had invited a representative sample of these sectors from its own database and did some outreach work to identify key stakeholders where gaps existed, however travel and registration costs may have been prohibitive for small service agencies or those on the front line without administrative or research budgets to cover costs. The MHCC limited the eligibility for available subsidies to participants with lived experience and their families or caregivers. In order to enhance reach, more subsidies could be offered to small organizations, and/or video conferencing or webinar technology could be used. The latter option was considered but rejected during the planning phase due to concerns about costs and impact on in-person participation.

Others thought that EA contributions could have been facilitated and supported better, and that EAs should have been more involved in drafting the consensus statement. While the conference went to great lengths to accommodate and heavily weight inclusion of lived experience, the EA experience in the end was less than optimal. These efforts included the special role accorded the 7-person EA panel, having an EA as the opening speaker, and including additional EAs in the audience, all of whose costs were covered. In 
addition the panel members received a small honorarium. Youth voice would have been strengthened if all table discussions included at least one youth (most did but a few did not), and if all young people had been able to meet together as a caucus a few times. In addition, while clinical help was available on site and a quiet room was made available, more support for EAs was needed. Options for future consideration include having a clinician ally (preferably a relatively young clinician) present when EAs meet.

While there was a family member at most tables, families also voiced concern about the ability to have their voices heard. Specifically, some disagreements arose during plenary discussions on some points that were raised by family members and EAs, which caused distress in some instances. Following the conference, MHCC staff had discussions with a few family organizations and the family members on the Jury to explore what could have been done differently. It was concluded that in some situations it is more effective to enable family members and youth to first hold separate discussions and that their plenary contributions be well facilitated.

Lastly, any "by invitation only" conference will have inherent representational biases. The first bias arises from the institution's own database, which is rarely truly representative. So while the MHCC developed a representative sample of people from its database to mirror the range of stakeholders whose voices needed to be included, the source database likely has an inherent bias of organizations and individuals that are supportive of MHCC efforts, and constituencies to which the MHCC has made outreach efforts. For example, because the MHCC has not had many initiatives that engaged First Nations, Inuit or Metis (FN-I-M) peoples, there are relatively few representatives from the indigenous communities in the database. Secondly, the selection process was not fully random and individual bias may have been introduced in selecting one individual over another. A combination of random sampling, advertising the conference more widely, and offering a wider range of targeted subsidies could reduce this bias.

From a planning perspective, despite the significant effort that went into preparing for the event, a number of additional advance activities were suggested that might have been helpful. These include having the Jury, Advisory, and EA Innovator groups meet to get to know each other prior to the event; better delegate preparation to enable them to make more meaningful contributions to the dialogue discussions; working with presenters to ensure material is accessible to all audiences, and focussing Jury efforts on refining previously developed materials based on the Conference discussions.

Despite these areas for improvement, if, as Lomas and Brown (2009) suggest, the influence of consensus conferences in the policy domain is perhaps greatest with respect to advancing new concepts and ways of thinking, then the Conference appears already to have had a significant impact, based on the feedback from informants in this case study. Other legacies of the event may include providing more general education (Kosecoff et al., 1987) about the evidence on emerging adulthood as a life stage that requires special attention from a mental health perspective, and in introducing participatory approaches into national policy making (Nielsen et al., 2006), which can be important within the Canadian health policy context. At the practice level, the longer-term impact of the Conference will depend on the presence of change champions and leaders, as well as the receptivity of organizations to hear and respond to feedback and organizational capacity to undertake reform. 
For the MHCC, as a national organization that itself does not have a mandate to implement change, knowledge exchange mechanisms that can influence policy and practice indirectly, through individual, organizational, and system level influence, are potentially powerful levers for change (Howlett, 1991; Mulvale, Chodos, Bartram, MacKinnon, \& Abud, 2014). At the same time, one of the limitations of this research is that it is not possible to know if actions reported since the Conference are directly attributable to the event. As Boyko et al. (2012) argues, while various forms of policy dialogues can contribute to policy making, direct attribution is not possible due to the complexity of policy processes. Another limitation is that it is difficult to capture the full range of Conference attendee perspectives in a small sample of key informants. Nonetheless, every attempt was made to select a diverse range of perspectives, and triangulation of the interview data with participant surveys and other sources showed a high level of consistency. Furthermore, the time frame of the analysis limits reporting of capacities developed and actions taken to the short term. Additional research will be needed to understand the medium and longer-term influence of the Conference on mental health policy and practice.

\section{CONCLUSION}

In its role as convener and facilitator of cross-jurisdictional and cross-sectoral collaboration, the MHCC helped to create and mobilize evidence on a complex policy topic by using a consensus conference process. Although the full impact of the Conference will take several years to manifest, early signs from this case study are that careful attention to the meeting environment, participant mix, and use of evidence has resulted in strengthened individual capacities to move evidence from the Conference into action in policy and practice. The Conference also seems to have established strong policy advocacy communities, a common understanding and language rooted in evidence, and new ideas and ways of thinking about the issue of EA mental health that are already beginning to shape the policy and practice landscape in Canada. The innovations on the consensus conference approach that were introduced, such as careful deliberation and mechanisms for feedback by delegates to the Jury, the direct incorporation of lived experience through the EA Innovator panel, and the engagement of FN-I-M youth groups following the conference, are worth continuing in future consensus conferences in the mental health domain in Canada.

\section{ENDNOTES}

1 The four Conference themes were (1) Defining emerging adulthood as a stage of life; (2) Bridging the gap between child and youth and adult mental health services; (3) Transitions across service systems; and (4) Mechanisms for improving mental health system responsiveness.

2 The consensus statement was not finalized until the fall of 2016 after months of consultations with the Jury, EA Innovators, and First Nations, Inuit, and Métis stakeholders. Normally statements are presented to delegates on the final morning of a consensus conference, and then released in final form within a few weeks or months of the conference. The MHCC adapted this part of the process in order to properly integrate all voices and perspectives, especially those who were deemed underrepresented at the actual event.

3 EA, family member (FM), service provider (SP), policy maker (PM)

4 EA Innovator (EA), Jury member (JM), Advisory Group member (AG) and general delegate (GD)

5 Justice, education, child welfare, and mental health. 


\section{REFERENCES}

Arnett, J. (2000). Emerging adulthood: A theory of development from the late teens through the twenties. American Psychologist, 55(5), 465-480.

Boyko, J., Lavis, J., Abelson, J., Dobbins, M., \& Carter, N. (2012). Deliberative dialogues as a mechanism for knowledge translation and exchange in health systems decision-making. Social Science \& Medicine, 75, 1938-1945.

Campbell, J. L. (2002). Ideas, politics and public policy. Annual Review of Sociology, 28, 21-38. doi:10.1146/annurev. soc.28.110601.141111

Davidson, S., \& Cappelli, M. (2011). We've got growing up to do: Transitioning from child and adolescent mental health services to adult mental health services. Ottawa: Ontario Centre of Excellence for Child and Youth Mental Health.

Di Rezze, B., Nguyen, T., Mulvale, G., Barr, N., Longo, C., \& Randall, G. E. (2016). A scoping review of evaluated interventions addressing developmental transitions for youth with mental health disorders. Child: Care, Health \& Development, 42(2), 176-187. doi:10.1111/cch.12306

Embrett, M., Randall, G. R., Longo, C., Nguyen, T., \& Mulvale, G. (2016). Effectiveness of health system services and programs for youth to adult transitions in mental health care: A systematic review of academic literature. Administration and Policy in Mental Health and Mental Health Services Research, 43(2), 259-269. doi:10.1007/ s10488-015-0638-9

Fink, A., Kosecoff, J., Chassin, M., \& Brook, R. H. (1984). Consensus methods: Characteristics and guidelines for use. American Journal of Public Health, 74(9), 979-983.

Gauvin, F.-P. (2014). Understanding policy developments and choices through the "3-i" framework: Interests, ideas and institutions. Montreal, QC: National Collaborating Centrre for Healthy Public Policy. Retrieved June 6, 2016, from http://www.ncchpp.ca/docs/2014_ProcPP_3iFramework_EN.pdf

Harrison, S. (2001). Policy analysis. In N. Fulop, P. Allen, A. Clarke, \& N. Black (Eds.), Studying the organisation and delivery of health services (pp. 90-106). London: Routledge.

Houston, D., \& Richardson, L. (2000). The politics of air bag safety: A competition among problem definitions. Policy Studies Journal, 28(3), 485-501.

Howlett, M. (1991). Policy instruments, policy styles, and policy implementation: National approaches to theories of instrument choice. Policy Studies Journal, 7(2), 1-21.

Howlett, M., Ramesh, M., \& Perl, A. (2009). Studying public policy: Policy cycles and policy subsystems. Toronto, Ontario: Oxford University Press.

Institute of Health Economics. (2016). Consensus Development Conference Series. Retrieved August 31, 2015, from http:// www.ihe.ca/research-programs/knowledge-transfer-dissemination/consensus-development-conference-series

Jacoby, I. (1988). Evidence and consensus. Journal of the American Medical Association, 259(20), 3039.

Kingdon, J. W. (1995). Agendas, alternatives and public policies (2nd ed.). New York: Longman.

Kosecoff, J., Kanouse, D. E., Rogers, W. H., McCloskey, L., Monroe Winslow, C., \& Brook, R. (1987). Effects of the National Institutes of Health Consensus Development Program on physician practice. Journal of the American Medical Association, 258(19), 2708-2713.

Lavis, J., Boyko, J., Oxman, A., Lewin, S., \& Fretheim, A. (2009). SUPPORT tools for evidence-informed health policymaking (STP) 14: Organising and using policy dialogues to support evidence-informed policymaking. Health Research Policy and Systems, 7(S1), S14. doi:10.1186/1478-4505-7-S1-S14

Lincoln, Y., \& Guba, E. (1985). Naturalistic inquiry. Beverly Hills, CA: Sage Publications.

Lomas, J., Anderson, G., Enkin, M., Vayda, E., Roberts, R., \& MacKinnon, B. (1988). The role of evidence in the consensus process: Results from a Canadian consensus exercise. Journal of the American Medical Association, 259(20), 3001-3005. doi:jama.1988.03720200023027

Lomas, J., \& Brown, A. D. (2009). Research and advice giving: A functional view of evidence-informed policy advice in a Canadian Ministry of Health. Millbank Quarterly, 87(4), 903-926.

McGlynn, E., Kosecoff, J., Brook, R. (1990). Format and conduct of consensus development conferences: A multination comparison. International Journal of Technology Assessment in Health Care, 6(3), 450-469. doi: DOI: http:// dx.doi.org/10.1017/S0266462300001045

McGorry, P. (2007). The specialist youth mental health model: Strengthening the weakest link in the public mental health system. Medical Journal of Australia, 187(7), S53-56. 
Mental Health Commission of Canada. (2012). Changing directions, changing lives: The mental health strategy for Canada. Calgary, AB: MHCC.

Mental Health Commission of Canada. (2015a). Consensus Conference on the Mental Health of Emerging Adults, November 2015-Collated input from delegates and EA panel on the Consensus Statement. (Internal document, Trans.). Ottawa, ON: Mental Health Commission of Canada.

Mental Health Commission of Canada. (2015b). Consensus Conference on the Mental Health of Emerging Adults, November 2015-Capture of plenary presentations and audience interactive sessions (Prepared by Ascribe for the Mental Health Commission of Canada, Trans.). Ottawa: Mental Health Commission of Canada.

Mental Health Commission of Canada. (2015c). Taking the next step forward: Building a responsive mental health and addictions system for emerging adults. Ottawa, ON: Mental Health Commission of Canada.

Miles, M. B., Huberman, A. M., \& Saldana, J. (2013). Qualitative data analysis: A methods sourcebook (3rd ed.). Thousand Oaks, CA: Sage Publications.

Mulvale, G., Chodos, H., Bartram, M., MacKinnon, M.-P., \& Abud, M. (2014). Engaging civil society through deliberative dialogue to create the first mental health strategy for Canada: Changing directions, changing lives. Social Science \& Medicine, 123, 262-268.

Mulvale, G., Nguyen, T., Miatello, A., Embrett, M., Wakefield, P., \& Randall, G. (2016). Lost in transition or translation? Care philosophies and transitions between child and youth and adult mental health services: A systematic review. Journal of Mental Health. doi:http://www.tandfonline.com/doi/full/10.3109/09638237.2015.1124389

Murphy, M. K., Black, N. A., Lamping, D. L., McKee, C. M., Sanderson, C. F., Askham, J., \& Marteau, T. (1998). Consensus development methods, and their use in clinical guideline development: A review. Health Technology Assessment, 2(3).

Nielsen, A., Hansen, J., Skorupinski, B., Ingensiep, H.-W., Lassen, J., \& Sandoe, P. (2006). Consensus conference: Manual. The Hague, Netherlands: LEI, onderdeel Wageningen UR.

Sabatier, P. A. (1999). The need for better theories. In P. A. Sabatier (Ed.), Theories of the policy process (pp. 3-18). Boulder, CO: Westview Press.

Schwandt, T. (2007). Triangulation. In The Sage dictionary of qualitative inquiry: Thousand Oaks, CA: Sage Publications Ltd.

Singh, S., Paul, M., Ford, T., Kramer, T., McLaren, S., Hovish, K., ...White, S. (2010). Process, outcome and experience of transition from child to adult mental healthcare: Multiperspective study. The British Journal of Psychiatry, 197(4), 305-312.

Stone, D. (2001). Policy Paradox: The Art of Political Decision Making. New York: Norton.

Walt, G., Shiffman, J., Schneider, H., Murray, S., Brugha, R., \& Gilson, L. (2008). 'Doing' health policy analysis: Methodological and conceptual reflections and challenges. Health Policy and Planning, 23, 308-317.

Yin, R. (2003). Case study research design and methods (Third ed. Vol. 5). Thousand Oaks, California: Sage Publications. 


\title{
Mobilisation des connaissances et politiques de santé mentale : apprentissages tirés de la Conférence consensuelle canadienne sur la santé mentale des adultes émergents
}

\author{
Gillian Mulvale et Christina Roussakis \\ Université McMaster \\ Christopher Canning, Despina Papadodoulos et Francine Knoops \\ Commission de la santé mentale du Canada
}

\begin{abstract}
RÉSUMÉ
Cette étude de cas examine comment la Conférence consensuelle sur la santé mentale des adultes émergents, tenue par la Commission de la santé mentale du Canada en 2015, peut avoir une incidence sur les politiques et les pratiques de santé mentale au Canada. Elle se fonde sur des entrevues menées auprès de 14 délégués et déléguées ayant participé à la conférence. Les participants et participantes ont fait l'éloge d'innovations comme l'inclusion d'un panel d'adultes émergents fournissant leurs commentaires sur toutes les discussions ainsi que les efforts consentis pour rendre le processus d'établissement de consensus aussi pertinent que possible dans le contexte politique canadien. Les résultats révèlent que les conférences consensuelles sont un moyen prometteur de mettre en application la Stratégie en matière de santé mentale pour le Canada grâce aux changements qu'elles permettent au niveau tant des politiques que des pratiques.
\end{abstract}

Gillian Mulvale, DeGroote School of Business, Université McMaster, Hamilton, Ontario; Christina Roussakis, DeGroote School of Business, Université McMaster, Hamilton, Ontario; Christopher Canning, Commission de la santé mentale du Canada, Ottawa, Ontario; Despina Papadodoulos, Commission de la santé mentale du Canada, Ottawa, Ontario; Francine Knoops, Commission de la santé mentale du Canada, Ottawa, Ontario.

Les auteurs souhaitent remercier les répondants et répondantes pour les commentaires et les opinions qu'ils ont exprimés dans le cadre de ces travaux.

La correspondance concernant cet article devrait être acheminée à Gillian Mulvale, DeGroote School of Business, McMaster University, Ron Joyce Centre, 4350, South Service Road, Burlington (Ontario) L7L 5R8. Tél : 905 525-9140, poste 28190; cellulaire : 289 983-0741; courriel : mulvale@mcmaster.ca. 
Mots clés : politique de santé mentale, application des connaissances, adultes émergents, santé mentale, conférence consensuelle, contexte politique, développement des capacités

\begin{abstract}
This case study explores how the Consensus Conference on the Mental Health of Emerging Adults, hosted by the Mental Health Commission of Canada in 2015, can impact mental health policy and practice in Canada. The study draws on interviews from 14 delegates who attended the conference. Participants praised innovations such as the inclusion of an emerging adult panel that provided feedback on all discussions, and efforts to make the consensus-building process meaningful in the Canadian policy context. Findings suggest that consensus conferences are a promising way to operationalize the Mental Health Strategy for Canada through policy and practice changes.
\end{abstract}

Key words: mental health policy, knowledge translation, emerging adults, mental health, consensus conference, policy context, capacity development

\title{
CONTEXTE
}

Les jeunes en âge de vivre la transition, désignés ici comme les adultes émergents, sont définis comme une population prioritaire qui doit être mieux comprise et bénéficier de services et d'une approche adaptés en matière de politiques de santé, particulièrement durant la transition entre les soins pour enfants et jeunes et les services de santé mentale et de lutte à la toxicomanie pour adultes, tel que mentionné dans Changer les orientations, changer des vies : stratégie en matière de santé mentale pour le Canada (la Stratégie; Commission de la santé mentale du Canada, 2012). Dans le domaine de la santé mentale, le terme adulte émergent est utilisé de plus en plus couramment pour désigner les adolescents et adolescentes et les jeunes adultes de 16 à 25 ans qui vivent une période de croissance et de développement considérable sur les plans social, intellectuel, psychologique et neurologique (Arnett, 2000). Le terme émergent souligne l'aspect dynamique de cette étape de la vie, qui ne se limite pas à une période définie uniquement par l'âge chronologique. Dans certaines études, l'âge adulte émergent s'étend de 14 à 29 ans. La littérature internationale et canadienne a recensé des difficultés propres à ce groupe d'âge, mais les progrès réalisés dans le domaine demeurent marginaux (Davidson et Cappelli, 2011; Di Rezze et al., 2016; Embrett, Randall, Longo, Nguyen et Mulvale, 2016; McGorry, 2007; Mulvale et al., 2016; Singh et al., 2010). En effet, bien que différentes initiatives locales et nationales aient été lancées au Canada, la Commission de la santé mentale du Canada (CSMC) estimait qu'il fallait en faire plus.

En septembre 2015, en partenariat avec le Centre hospitalier pour enfants de l'est de l'Ontario, la CSMC a dévoilé Faire un pas vers le futur : bâtir un système de services en santé mentale et en toxicomanie adapté aux besoins des adultes émergents (Faire un pas) (Commission de la santé mentale du Canada, 2015c), qui présente et analyse en détail l'état actuel des politiques et des pratiques en matière de transition des jeunes vers les services de santé mentale et de lutte à la toxicomanie pour adultes. À la suite de ce rapport, la CSMC a financé et organisé une conférence consensuelle intitulée La santé mentale des adultes émergents : faire de la transition une priorité au Canada (la conférence), qui a eu lieu en novembre 2015. Les 
organisateurs et organisatrices de la conférence ont adopté Faire un pas comme document de référence et se sont également inspirés de données probantes tirées d'études et de témoignages d'experts et d'expertes pour orienter les questions liées aux politiques, les présentations des conférenciers et les discussions. Deux cents participants et participantes de toutes les provinces et de tous les territoires, à l'exception du Nunavut, ont assisté à l'événement. La conférence a rassemblé des adultes émergents, des proches aidants, des décideurs des gouvernements provinciaux, territoriaux et fédéral, des chercheurs, des représentants et représentantes d'organismes de santé mentale et des cliniciens et cliniciennes.

Le terme conférence consensuelle désigne une réunion structurée ayant pour objet de « définir le degré d'accord sur des sujets controversés » (Fink, Kosecoff, Chassin et Brook, 1984) au moyen d'une approche qui a été employée dans de nombreuses situations depuis 1977 (Jacoby, 1988), notamment par les National Institutes of Health (NIH), aux États-Unis, pour évaluer des technologies médicales et des produits de recherche biomédicale (Fink et al., 1984). Ces conférences des NIH ont donné lieu à des énoncés consensuels sur des recherches existantes et permis d'élaborer des lignes directrices sur diverses pratiques cliniques. Chez nous, la Société des obstétriciens et gynécologues du Canada s'est servie de cette approche pour élaborer des lignes directrices cliniques (Lomas et al., 1988), et, plus récemment, l'Institute of Health Economics de l'Alberta (2016) a tenu plusieurs conférences consensuelles pour formuler des recommandations sur l'élaboration de politiques.

Habituellement, cinq ou six questions sont posées avant la tenue de l'événement à un panel (ou jury), qui est invité à y réfléchir à la lumière des données empiriques qui lui sont présentées. Ces questions délimitent la portée et l'orientation des discussions qui seront menées lors de la conférence. Le jury fonde ses délibérations sur les données probantes disponibles en vue de produire un énoncé consensuel, qui est présenté aux fins de discussion et d'adoption le dernier jour de la conférence, avant d'être diffusé à plus large échelle (Jacoby, 1988). L'énoncé peut être peaufiné après la conclusion de l'événement.

La CSMC a légèrement modifié ce format pour sa propre conférence. En prévision de l'événement, deux conseils consultatifs - un panel d'adultes émergents (les adultes émergents innovateurs) et un groupe d'experts de premier plan et de décideurs en santé mentale — ont participé à la définition du format, des thèmes et des résultats attendus de la conférence. Les adultes émergents innovateurs et les délégués ont également fourni de la rétroaction durant l'événement, ce qui n'est généralement pas le cas lors des conférences consensuelles. La conférence était basée sur la présentation de données probantes par 12 conférenciers, qui ont ensuite traité de questions précises formulées par les conseils consultatifs. Chacun de ces exposés traitait d'un des quatre thèmes stratégiques interreliés de la conférence ${ }^{1}$. Au terme de chaque bloc de présentations thématiques, les 16 membres du jury, les adultes émergents innovateurs et les délégués avaient l'occasion de poser des questions aux conférenciers. En outre, pendant que le jury et les adultes émergents innovateurs débattaient de chacun des thèmes, les délégués échangeaient en groupes restreints; des animateurs et animatrices recueillaient ensuite cette rétroaction de groupe et consignaient les commentaires individuels, qu'ils soumettaient directement au jury et aux adultes émergents innovateurs. Le dernier matin de la conférence, le jury a présenté l'ébauche de son énoncé consensuel aux délégués aux fins de discussions en petits groupes et en plénière. Le jury et les adultes émergents innovateurs ont examiné la rétroaction orale et écrite fournie par les délégués dans les mois qui ont suivi la conférence et dans le cadre du processus de peaufinage de l'énoncé consensuel². 
Ces conférences consensuelles sont un type particulier de dialogue sur les politiques (Lavis, Boyko, Oxman, Lewin et Fretheim, 2009). La réussite du dialogue repose sur la présence d'un cadre de réunion approprié, sur la composition du groupe de participants et participantes et sur l'utilisation de données probantes (Boyko, Lavis, Abelson, Dobbins et Carter, 2012). Un environnement approprié comprend la présence d'animatrices et d'animateurs qualifiés, des attentes prédéterminées en matière de consensus et des recommandations claires et précises (Fink et al., 1984). Les participants et participantes à la conférence doivent être en mesure de représenter leurs commettants et de mettre en œuvre les conclusions tirées, ou être reconnus comme des experts et expertes, notamment comme personnes ayant vécu la maladie mentale. Aussi, des données probantes sur le domaine étudié doivent être disponibles et servir d'assise pour une définition consciencieuse des enjeux à débattre (Fink et al., 1984; McGlynn, Kosecoff et Brook, 1990; Murphy et al., 1998). La conférence consensuelle se distingue de la plupart des dialogues de politique par l'accent placé sur la tentative d'atteindre un certain consensus parmi les participants et participantes, même si cet objectif ne se concrétise pas toujours (Lavis et al., 2009). Elle a pour motif implicite d'approuver « officiellement » certaines recommandations lorsque celles-ci reflètent les données probantes disponibles et la rétroaction d'un panel de jurés respectés et crédibles (Lomas et al., 1988, p. 3004). Le format de la conférence consensuelle a le potentiel d'élargir et de nuancer le débat public, d'influencer l'élaboration des politiques et la prise de décisions politiques ainsi que d'introduire des procédures participatives à la prise de décisions (Nielsen et al., 2006).

Comme mentionné par Murphy et al. (1998), il peut être tentant de juger du succès d'une conférence consensuelle par sa capacité à produire « des résultats qui sont non seulement justes, mais qui sont susceptibles d'exercer une influence » (p. 22); toutefois, la légitimité accordée à la participation du public et aux approches délibératives utilisées pour la prise de décisions peut varier d'une administration à l'autre (Nielsen et al., 2006). Même dans les cas où une conférence consensuelle génère des résultats limités en matière d'influence directe des politiques, l'événement peut remplir une précieuse fonction éducative susceptible de promouvoir la mise en œuvre de ses conclusions et l'adoption de mesures à l'échelle locale (Kosecoff et al., 1987). Lomas et Brown (2009) indiquent que dans les sphères stratégiques, les conférences consensuelles ont une influence accrue sur la création de concepts et de façons de penser, qui peut être amplifiée par la prise en considération de commentaires fournis par des experts et expertes et par des membres du public non-experts (Lomas et al., 1988; Nielsen et al., 2006).

Pour la CSMC, un organisme national au sein d'une fédération où les provinces et les territoires sont les principaux responsables de la prestation des soins de santé, il importe de déterminer si l'approche de la conférence consensuelle peut favoriser l'adoption des données probantes et la transposition de celles-ci dans l'élaboration des politiques et la prestation des services. En nous servant de la conférence comme une étude de cas qualitative, nous avons cherché à déterminer dans quelle mesure et de quelle manière les conférences consensuelles pouvaient influencer les politiques et les pratiques en matière de santé mentale au Canada. Nous voulions connaître le point de vue des délégués sur leur propre capacité à adopter des pratiques et des politiques fondées sur des données probantes à la suite de leur participation à la conférence; sur l'utilité de cette approche dans le contexte canadien; et sur l'influence éventuelle de la conférence sur leurs activités ultérieures. L'examen des apprentissages tirés de cette étude de cas nous révèle que les conférences consensuelles sont d'importants outils de mobilisation des connaissances et qu'elles procurent une occasion unique 
aux parties prenantes de mieux harmoniser les politiques et la prestation des services de santé mentale avec les preuves disponibles et, ce faisant, de contribuer à la mobilisation et à la mise en œuvre des recommandations contenues dans la Stratégie.

\section{MÉTHODOLOGIE}

En utilisant la conférence comme cas, cette étude de cas qualitative (Yin, 2003) étudie les conférences consensuelles comme véhicule de mobilisation des connaissances et comme moyen de renforcer les capacités des individus et des organisations en vue d'influencer les politiques et les pratiques en matière de santé mentale au Canada. Un des principaux atouts des études de cas est leur capacité à définir les « leçons apprises » pouvant servir à améliorer les pratiques dans d'autres contextes (Lincoln et Guba, 1985). Conformément à l'approche de l'étude de cas, consistant à faire appel à des données théoriques existantes pour accroître la rigueur des travaux (Harrison, 2001; Yin, 2003), nous avons adopté le modèle conceptuel de Boyko et al. (2012), basé sur les particularités du dialogue et les effets attendus en matière de capacités comme cadre théorique orientant notre recherche. Selon ce modèle, il est possible de renforcer les capacités individuelles à court terme en améliorant la compréhension mutuelle; en nouant de nouvelles relations; en développant les compétences en communication; en renforçant la confiance et le sentiment de compétence; et en proposant de nouvelles perspectives sur les problèmes et les solutions en matière de politiques. Ce modèle veut également qu'à moyen terme, ces capacités individuelles puissent renforcer les capacités de l'organisation à influencer les programmes politiques, à élaborer et à adopter des politiques lorsque l'occasion se présente (Howlett, Ramesh et Perl, 2009). À long terme, cette amélioration pourrait également s'étendre à la capacité des systèmes à élaborer des politiques basées sur des preuves. Dans cette étude consacrée aux données recueillies dans les 9 mois qui ont suivi la conférence, nous nous attendons à constater principalement des effets à court terme.

De mai à août 2016, nous avons réalisé des entretiens téléphoniques de 30 à 45 minutes avec 14 déléguées et délégués ayant participé à la conférence expressément sélectionnés. Le tableau 1 présente le cadre d'échantillonnage par types de participant(e), qui visait à sonder une gamme variée de points de vue (adultes émergents, membres de la famille d'un adulte émergent, fournisseurs et fournisseuses de services, décideurs) ${ }^{3}$, de délégués et déléguées (adultes émergents innovateurs, membres du jury, membres du conseil consultatif, conférenciers, déléguées et délégués généraux) ${ }^{4}$ et de secteurs (santé, éducation, santé mentale, justice, protection de l'enfance) $)^{5}$, tout en tenant compte de la diversité géographique et culturelle des participants et participantes.

Le guide d'entretien semi-structuré sondait l'opinion des participants et participantes sur les apprentissages qu'ils avaient faits lors de la conférence, sur les mesures pertinentes qu'ils avaient prises depuis l'événement et sur des considérations politiques. Les entretiens ont été enregistrés et transcrits par des transcriptrices et transcripteurs professionnels. Le codage a été effectué selon une méthode déductive, en commençant par les thèmes dégagés à partir du cadre de Boyko et al. (2012), complétés par d'autres thèmes émergents (Miles, Huberman et Saldana, 2013). Les chercheurs ont codé et étudié les transcriptions au moyen du logiciel d'analyse qualitative NVivo 10. Au départ, deux chercheurs ont codé de façon indépendante un échantillon de contenu des entretiens et ont constaté un très haut degré d'accord. Tous les désaccords ont 
été débattus jusqu'à l'obtention d'un consensus. Le livre de codes ainsi créé a servi au codage du reste des entretiens.

Pour assurer la rigueur de la procédure, l'analyse des résultats des entretiens a été triangulée avec les preuves documentaires (Schwandt, 2007; Yin, 2003) provenant de trois sources : (a) les résumés écrits de trois téléconférences de bilan réunissant les membres du jury, du panel d'adultes émergents innovateurs et du conseil consultatif, tenues après la conférence, (b) les réponses des délégués aux questions posées dans le formulaire d'évaluation de la conférence $(n=97)$ (Commission de la santé mentale du Canada, 2015a), et (c) les notes prises lors de la conférence par un conseiller externe (Commission de la santé mentale du Canada, 2015b). Nous résumons ici les réponses au sondage d'évaluation, en nous attardant toutefois à la rétroaction obtenue grâce aux entretiens avec les répondantes et répondants clés en raison de la forte correspondance des résultats provenant des différentes sources de données. Ensuite, nous présentons les leçons apprises révélées par les commentaires des participants et participantes et par la rétroaction des organisateurs et organisatrices de la conférence consensuelle.

\section{RÉSULTATS}

Les données ont dégagé trois principaux thèmes : la rétroaction sur les processus et les caractéristiques de la conférence; les capacités accrues en matière d'utilisation des données probantes dans l'élaboration de politiques; et l'influence exercée sur l'élaboration de politiques depuis l'événement. Ces thèmes structurent notre présentation des résultats.

Tableau 1

\section{Cadre d'échantillonnage}

\begin{tabular}{lc}
\hline Types de participant(e) & Nombre \\
\hline Adultes émergents innovateurs & 2 \\
Membres de la famille d'un adulte émergent (1 membre du conseil consultatif, 1 membre du & 2 \\
jury) & 4 \\
Membres du jury (choisis par secteur—santé, éducation, santé mentale, justice, protection de & \\
l'enfance, etc. de partout au Canada) & 4 \\
Délégué(e)s : & \\
$\quad$ Décideur (1) & \\
Membre du conseil consultatif (1) & \\
Conférencier (1) & \\
$\quad$ Autre délégué général (1) & 2 \\
Personnel de la CSMC (1 analyste des politiques, 1 gestionnaire de programme) & 14 \\
Total & \\
\hline
\end{tabular}




\section{Processus et caractéristiques de la conférence}

En général, les répondants et répondantes ont émis une opinion favorable sur la conférence dans le sondage d'évaluation distribué à la fin de l'événement (voir figure 1); en effet, $86 \%$ des participantes et participants se sont dits satisfaits ou très satisfaits de leur expérience globale lors de la conférence, et $70 \%$ se sont dits satisfaits des occasions de dialogue et de réseautage offertes. Les taux de satisfaction étaient moins élevés lorsqu'il était question du volume d'information disponible pour la préparation à la conférence et la clarté des objectifs de l'événement (respectivement $57 \%$ et $59 \%$ des participantes et participants satisfaits).

Les commentaires recueillis au moyen du sondage révèlent une satisfaction générale à l'égard du cadre de réunion, de la composition du groupe de participants et participantes et de l'utilisation de données probantes. Un répondant a indiqué que la conférence était « très bien structurée et organisée » [DG2], bien que des suggestions d'améliorations aient été formulées (voir tableau 2, colonne 1). La durée de deux jours et demi a été jugée adéquate pour le contenu, mais le programme était « assez condensé » [CC3] selon certains participants et participantes, qui estimaient que l'événement aurait pu s'étendre sur " trois jours complets » [adultes émergents1]. De nombreux répondants et répondantes ont décrit la préparation à l'événement comme « très approfondie » et « très utile » [adultes émergents1]; toutefois, un membre de la famille faisant partie du jury s'est senti insuffisamment préparé pour «travailler aux côtés de personnes ayant beaucoup plus d'expérience » [MF1MJ].

La plupart des répondants et répondantes ont jugé appropriés les rôles du conseil consultatif, du jury et du panel d'adultes émergents innovateurs. Le panel d'adultes émergents innovateurs a été décrit comme

(suite à la page 29)

\section{Figure 1}

Satisfaction quant à la préparation à la conférence, aux objectifs de celle-ci, aux occasions de dialogue et à l'expérience globale

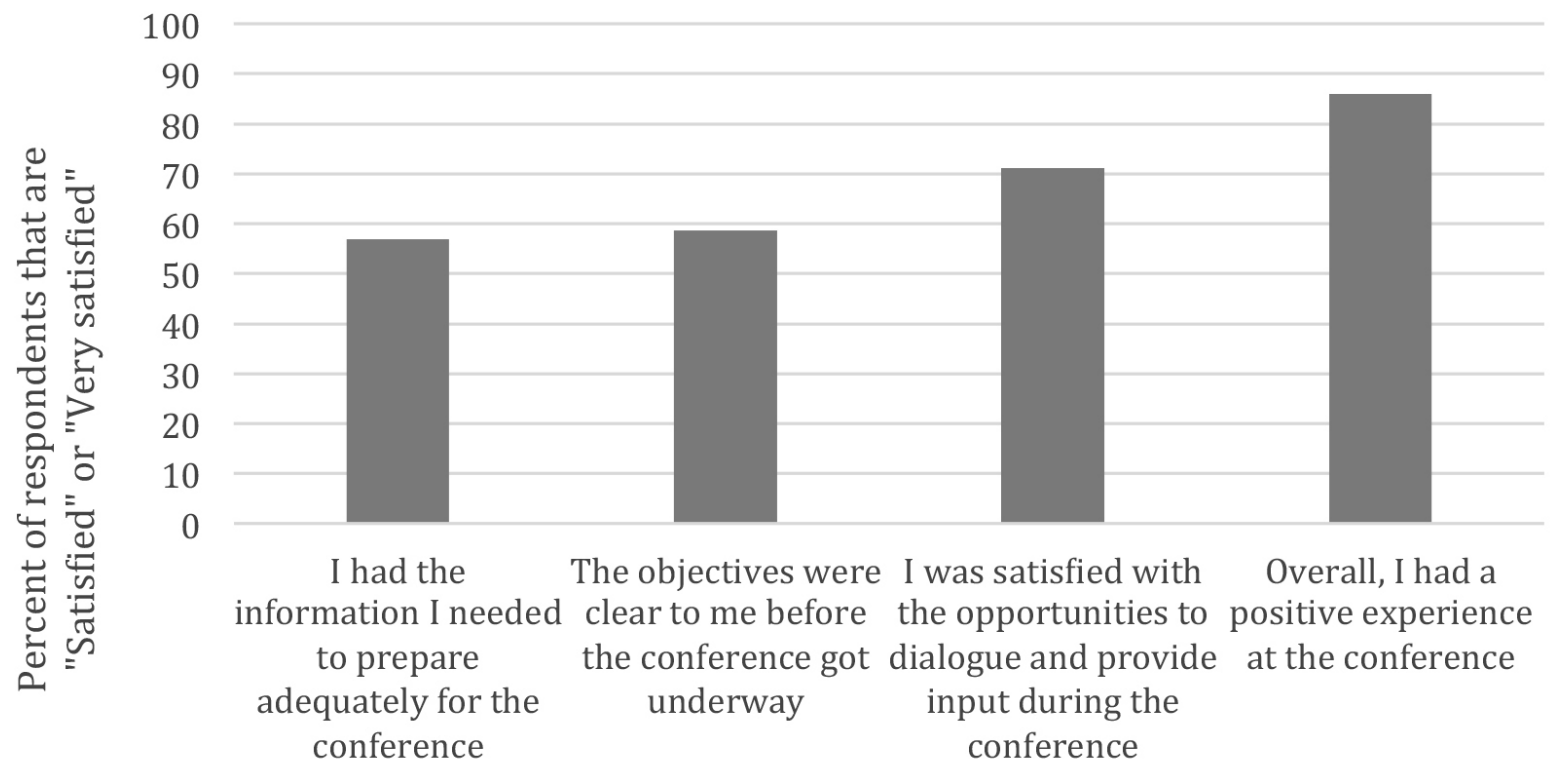




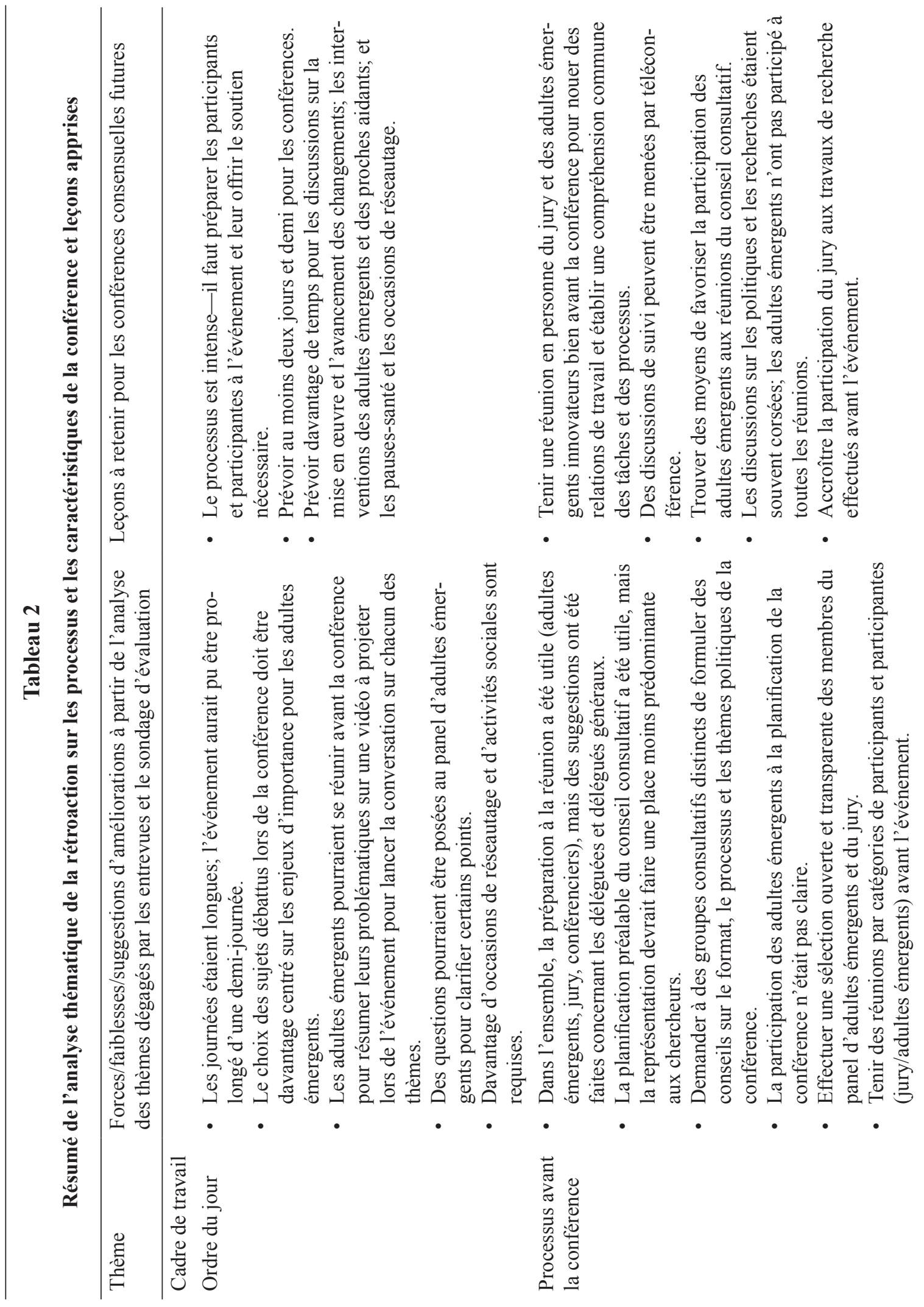




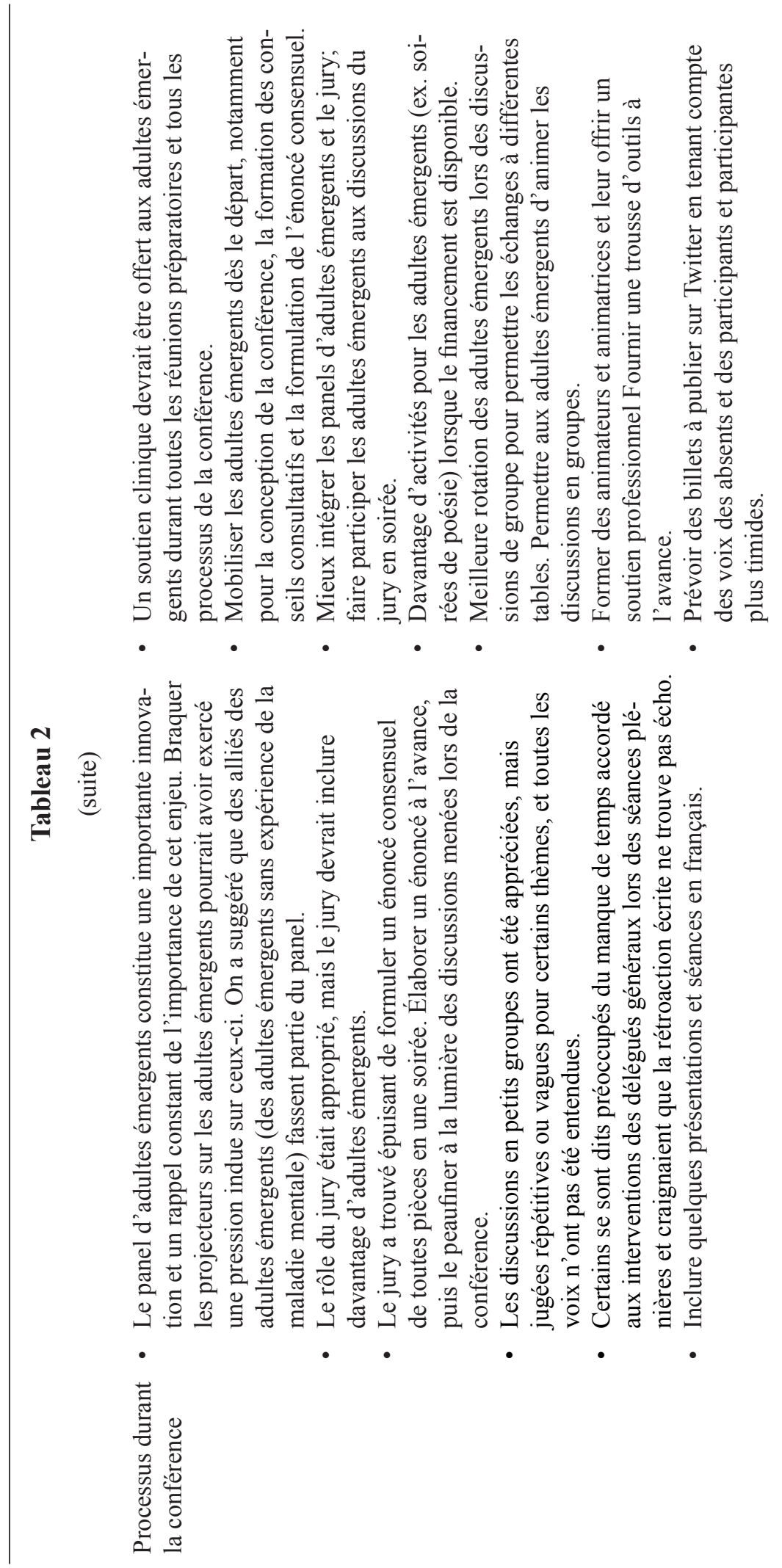




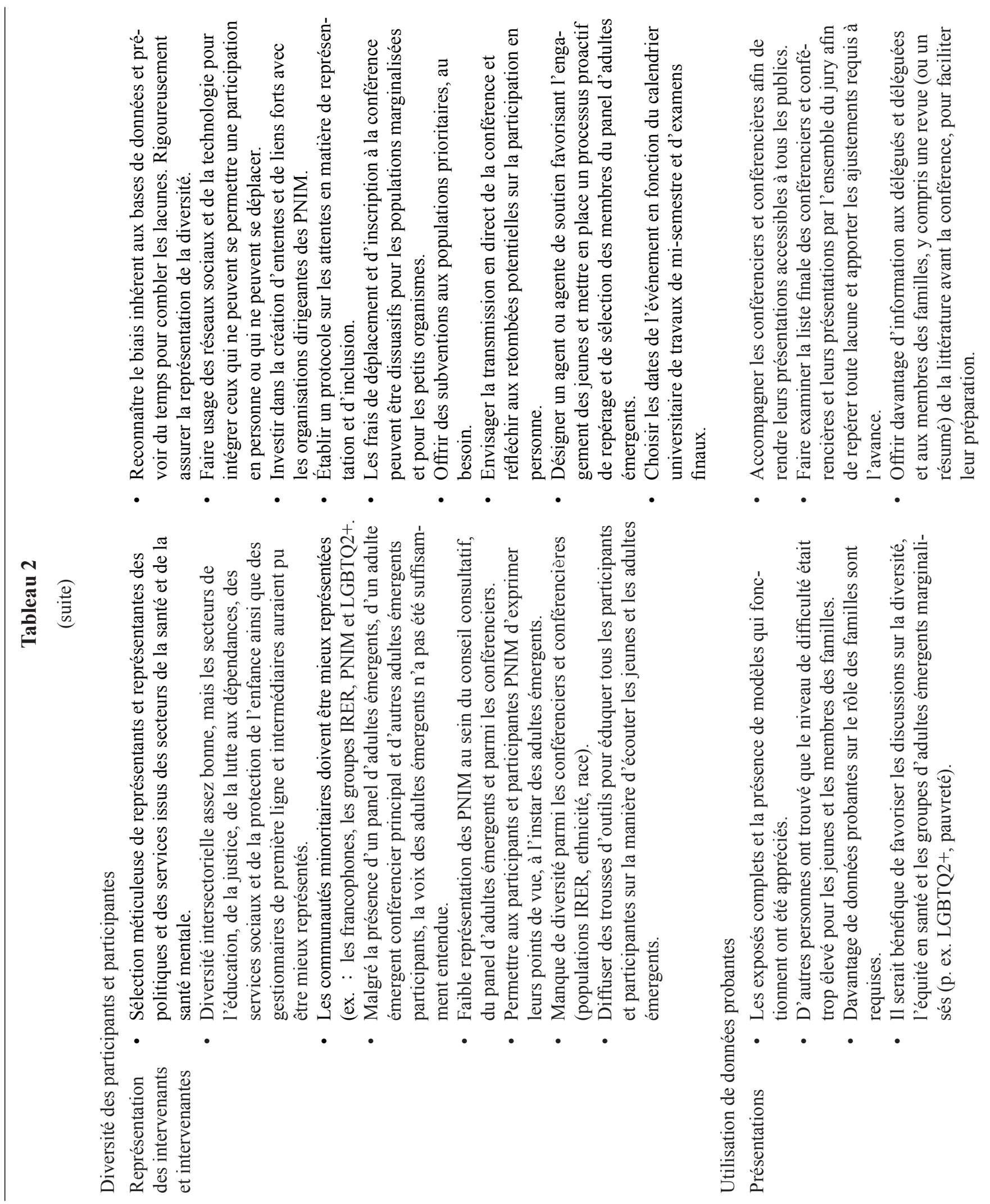




\section{(suite de la page 25)}

une caractéristique « novatrice » [DG4] qui « rappelle en tout temps » que les adultes émergents sont « le groupe dont il est question et qu'on cherche à servir » [MJ2]. Certains se sont toutefois demandé si le fait de mettre en lumière les adultes émergents avait exercé une pression indue et ont mentionné qu'un soutien clinique accru était requis. On a formulé plusieurs suggestions visant à centrer davantage la conférence sur les adultes émergents et à accroître la participation de ceux-ci à l'événement, que ce soit comme conférenciers et conférencières, membres du jury ou coauteurs de l'énoncé consensuel (Commission de la santé mentale du Canada, 2015a). On a également souhaité une plus grande interaction entre le panel d'adultes émergents et le jury. Les membres du jury ont indiqué qu'un énoncé consensuel provisoire pourrait être rédigé à l'avance en vue d'être peaufiné par le jury à la lumière des discussions menées lors de la conférence. La formulation de toutes pièces de l'énoncé consensuel au terme de deux longues journées de travail a été décrite comme « épuisante » [MJ1FS]. À cet égard, le soutien du personnel et des rédacteurs de la CSMC a été jugé « très utile et nécessaire » [MJ1FS].

Le processus de collecte des commentaires des délégués généraux tout au long de la conférence a généralement été apprécié. Certains répondants et répondantes ont mentionné que lors de conférences futures, les déléguées et délégués gagneraient à être mieux préparés aux discussions en petits groupes, par exemple au moyen de trousses d'outils sur les compétences d'écoute et de consultation des adultes émergents et des familles (Commission de la santé mentale du Canada, 2015a).

Sur le plan de la diversité des participants et participantes, ils ont été nombreux à trouver la conférence représentative. Un adulte émergent a indiqué que la conférence « avait réuni de nombreux intervenants prenant fait et cause pour les services de santé mentale destinés aux jeunes en âge de faire transition au Canada » (adultes émergents1). Certains répondants et répondantes trouvaient que les domaines de l'éducation, de la justice, de la lutte aux dépendances, des services sociaux et de la protection de l'enfance, de même que les gestionnaires de première ligne et de programmes ainsi que certaines populations auraient pu être mieux représentés. Par exemple, un délégué a mentionné que si quelques séances avaient été données en français, la représentation des francophones du Canada hors de l'Ontario aurait pu être meilleure. D'autres étaient d'avis que les membres des Premières nations, les Inuits et les Métis (PNIM) et les populations d'immigrants, de réfugiés et de groupes ethnoculturels ou racialisés (IRER) étaient sous-représentés.

Bien que le jury et la délégation présente à la conférence comptaient quelques PNIM, certains participants et participantes ont exprimé une inquiétude légitime concernant l'absence d'engagement préalable auprès des groupes et des délégués autochtones. Conséquemment, les recommandations émises dans l'énoncé consensuel ne reflètent pas adéquatement les réalités et les besoins urgents des PNIM. Tout en continuant à travailler avec le jury et les adultes émergents innovateurs sur l'énoncé consensuel après la conférence, la CSMC a rencontré les PNIM membres du jury et des jeunes représentants et représentantes de l'Assemblée des Premières Nations (APN), du Ralliement national des Métis (RNM) et d'Inuit Tapirisat du Canada (ITC) afin de définir des moyens de faire une place appropriée et adéquate aux besoins en matière de bien-être mental des adultes émergents autochtones dans l'énoncé consensuel final et de favoriser le partage de connaissances. Ces réunions ont raffermi les liens avec les chefs et les intervenants et intervenantes des PNIM.

Les opinions étaient partagées quant à l'efficacité des données de recherche présentées lors de la conférence. Certains répondants et répondantes ont trouvé « encourageant de constater ce qui fonctionnait déjà 
bien pour les services de santé mentale destinés aux jeunes en âge de faire la transition » [adultes émergents1] et étaient d'avis que les preuves étaient suffisamment nombreuses [DG2]. Cependant, un membre du conseil consultatif jugeait que les recherches présentées étaient difficiles à comprendre pour bien des jeunes et des membres des familles, ce qui a limité la capacité des délégués et déléguées à prendre des décisions éclairées [CC1]. Un membre de la famille d'un adulte émergent faisant partie du jury a mentionné que les données probantes sur l'importance des familles pour la santé mentale des adultes émergents étaient insuffisantes, mais que cette lacune pourrait refléter les limites des données existantes [MF1MJ]. Les quatre thèmes qui structuraient les discussions menées lors de la conférence ont été jugés appropriés, complémentaires et importants, mais on a indiqué que davantage d'importance aurait dû être accordée aux questions de diversité et d'équité pour les groupes d'adultes émergents marginalisés.

\section{Influence sur les capacités d'élaboration de politiques et de programmes basés sur des preuves}

Les personnes interrogées ont rapporté diverses façons dont leur participation à la conférence avait renforcé leur capacité à améliorer la santé mentale des adultes émergents, qui sont résumées au tableau 3. Conformément au modèle de Boyko et al. (2012), les répondants et répondantes ont révélé que les discussions qu'ils avaient eues à la conférence avaient amélioré la compréhension mutuelle, notamment en ce qui concerne le point de vue des adultes émergents. Un conférencier a indiqué : « Il n'existe pas d'experts plus qualifiés que les personnes qui ont parcouru le système à plusieurs reprises » [DG2]. Un adulte émergent a ajouté : «Je n'ai jamais vu les adultes émergents et les jeunes participer à l'élaboration des politiques de santé mentale. C'est bien de constater l'importance qu'on nous accorde ici » [adultes émergents2]. On a souligné la nécessité de mieux comprendre le point de vue des adultes émergents, car trop souvent, les gens

font leur part du travail, sans voir la situation sous l'angle d'une personne qui tente de s'orienter dans le système, [. . .] qui ignore vers qui se tourner tout en sachant que ses options sont limitées, et qui finit par conclure que la meilleure chose à faire est de se présenter aux urgences une fois de plus. [DG2]

L'engagement actif des adultes émergents dans autant d'aspects de la conférence a également inspiré l'adoption d'une perspective nationale sur les besoins uniques de certaines populations du Canada, y compris certains groupes minoritaires comme les peuples autochtones [DG4] parce que « nous devons comprendre tous les secteurs, toutes les couches de notre société, et la santé de tous ces individus. Ce faisant, nous augmentons notre capacité [. . . ] d'empathie et de réceptivité » [DG3]. D'autres répondants ont senti que la conférence avait élargi leur horizon, particulièrement en ce qui concerne « le large éventail de perspectives de partout au pays et de toutes les disciplines qui y étaient représentées » [MJ1FS].

Plusieurs personnes ont expliqué que les capacités avaient aussi été accrues grâce aux nouvelles relations établies entre les adultes émergents, les fournisseurs et fournisseuses de services, les membres des familles et les chercheurs. Un adulte émergent a affirmé qu' " au terme de la conférence consensuelle, après deux jours et demi d'échanges, énormément de liens, de communication et de rapports avaient été établis » [adultes émergents1]. Même des experts et expertes et des décideurs qui entretenaient déjà des liens solides au niveau national ont trouvé avantageux de nouer de nouvelles relations aux échelons provincial et local et de découvrir différentes initiatives communautaires [DG1]. Les délégués ont également amélioré leurs 


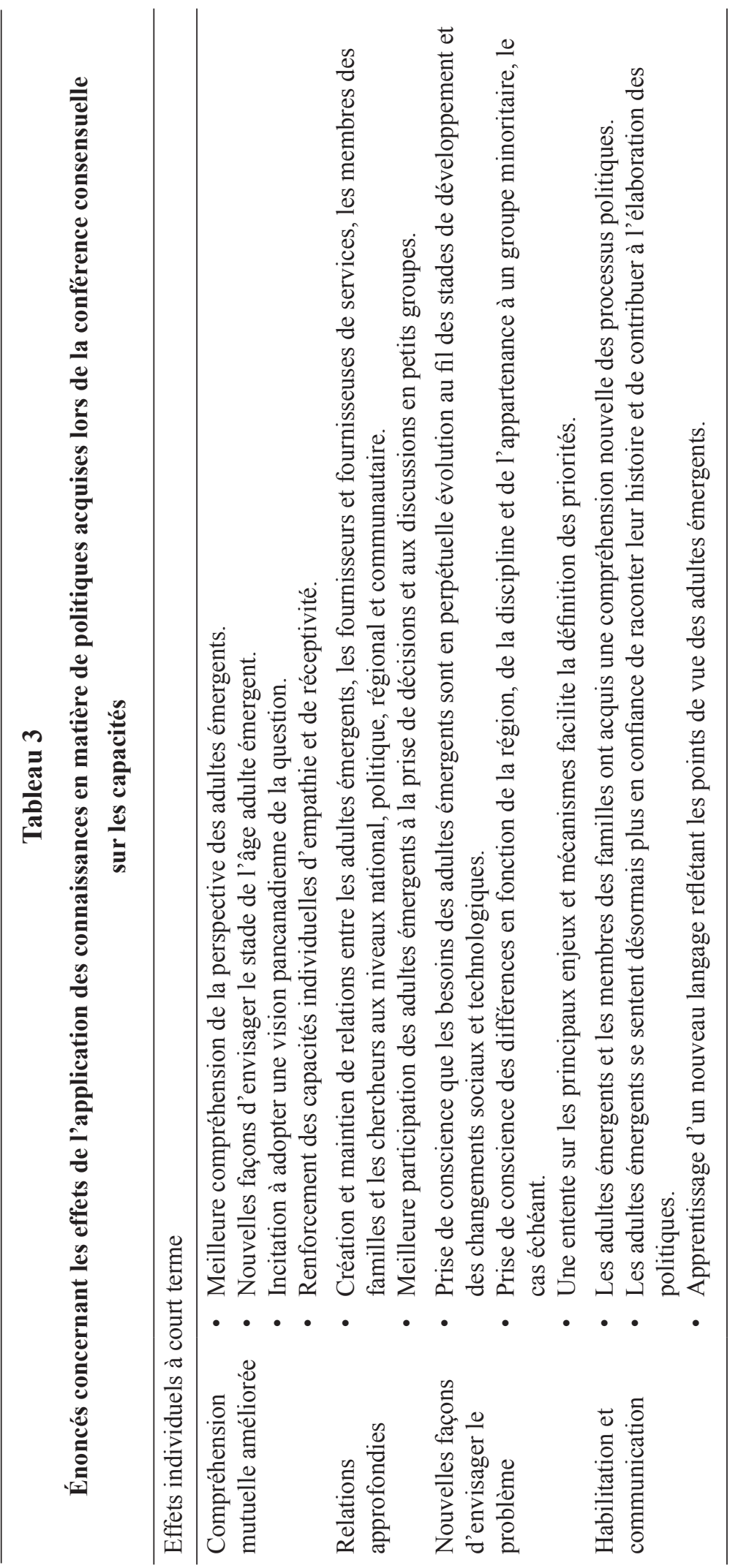




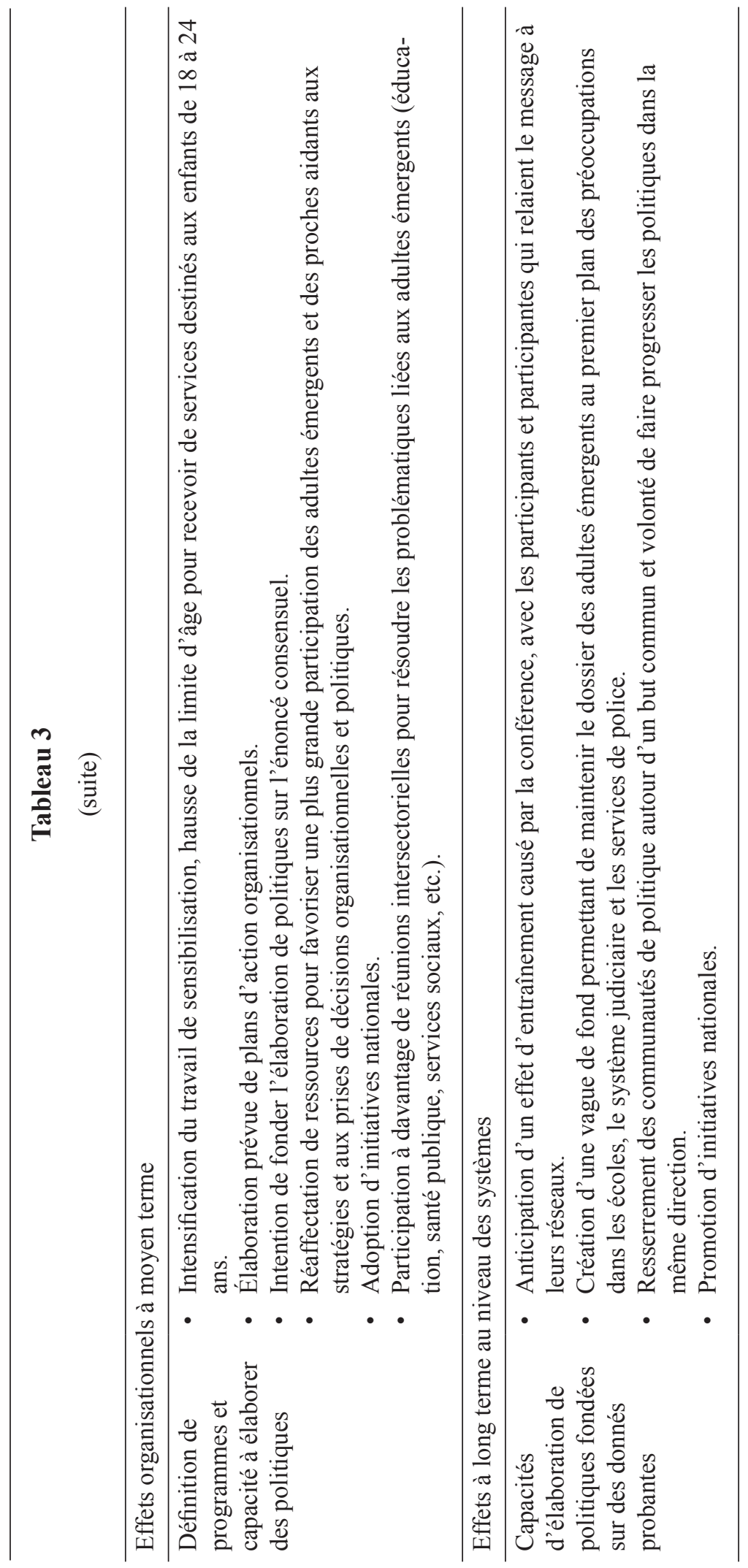




\section{(suite de la page 30)}

capacités en explorant de nouveaux moyens d'envisager la santé mentale à l'âge adulte émergent. Un délégué a pris conscience que les besoins des adultes émergents ne sont pas figés dans le temps et qu'en raison des changements sociaux et technologiques, il faut constamment développer ses capacités pour demeurer au fait de la réalité des adultes émergents et de leur santé mentale [DG3].

La conférence a inculqué aux adultes émergents et aux membres des familles des capacités précises leur permettant de mieux comprendre les processus d'élaboration des politiques et les facteurs requis pour engendrer des changements en matière de politiques. Un adulte émergent a dit avoir désormais « une idée très claire des étapes à franchir pour faire de la santé mentale des adultes émergents en âge de faire la transition une priorité » [adultes émergents1]. Un autre a expliqué :

Pour élaborer ou modifier [. . . ] une politique, des individus doivent se réunir autour d'une table pour écouter, les yeux dans les yeux, et dialoguer. Cette méthode vaut plus que les revues scientifiques. Elle vaut plus que des conférences écoutées passivement. Je crois que la meilleure façon d'aborder et de comprendre les détours épineux et fluctuants de la santé mentale et de modifier les politiques est la tenue de forums comme la conférence. [adultes émergents2]

Au fil du dialogue, les participants et participantes ont aussi commencé à énoncer leurs priorités d'action. Un adulte émergent a indiqué que « les conférences consensuelles sont idéales pour examiner un sujet d'une manière générale [. . .], puis cibler précisément les sujets qui doivent être débattus » [adultes émergents2]. Si les sujets sont aussi pointus, c'est parce que les participants et participantes « proviennent de secteurs divers et s'intéressent à différents aspects de la question. [. . .] Ils se rassemblent pour travailler de façon concertée et s'entendre sur [.. .] les principaux enjeux et [.. .] sur des mécanismes permettant d'harmoniser les politiques avec ces enjeux » [DG2]. D’autres répondantes et répondants se sont sentis plus habilités à influencer l'élaboration des politiques à la suite de la conférence; par exemple, des adultes émergents étaient plus confiants pour raconter leur expérience et « contribuer [ . . ] à formuler des recommandations sur les politiques » [adultes émergents2]. Un membre du jury a indiqué avoir appris à se servir de notions et d'un langage commun :

J'ai davantage confiance, car mon point de vue ne se limite plus à mon environnement immédiat, mais intègre une perspective plus large où certaines notions ont été validées, où j'ai beaucoup appris. Les nouvelles technologies, particulièrement celles qui sont utilisées par les adultes émergents eux-mêmes, font partie intégrante de la conversation. Ces éléments ont certainement changé la donne. [MJ2]

Dans l'ensemble, les répondants et répondantes n'ont pas directement évoqué le renforcement des capacités au niveau des organisations et des systèmes. Ce fait ne surprend pas étant donnée la courte période de temps qui s'était écoulée depuis la conférence. Les réponses au sondage révèlent que certains délégués et déléguées souhaitaient faire pression pour hausser la limite d'âge pour recevoir des services destinés aux enfants de 18 à 24 ans et pour élaborer des plans d'action organisationnels. Un membre du jury comptait faire fond sur l'énoncé consensuel final pour établir une stratégie organisationnelle sur les besoins en santé mentale des adultes émergents et pour « tendre la main [. . . ] à quelques-uns des jeunes qui ont pris la parole lors de la conférence, mais aussi pour aider des adultes émergents de notre région » à faire entendre leur voix [MJ3].

En ce qui concerne les systèmes, les membres du jury croient que la conférence aura un « effet d'entraînement », puisque les délégués diffusent les messages de l'événement [MJ2, MJ3] dans le 
cadre du processus d'échange de connaissances. Ce faisant, ils font «progresser le dossier » au sein d'organisations comme les écoles, le système judiciaire, les services policiers et d'autres entités ayant à cœur la santé mentale des adultes émergents [MJ2]. Certains répondants et répondantes ont affirmé que la conférence avait créé une « vague de fond » permettant de maintenir cet enjeu au premier plan des préoccupations [CC2FS] et croient que « plus les gens se mobiliseront autour du processus, plus cette lame de fond sera en mesure de changer la dynamique et de donner de l'élan à ce dossier » [MJ1FS]. On estime que la conférence a resserré les liens au sein des communautés politiques en établissant une définition commune du problème et des solutions potentielles qui y ont été présentées. La " poursuite d'un but commun » par différents groupes en vue de « faire progresser les politiques » [MJ2] peut favoriser une promotion plus efficace par ceux-ci. Un adulte émergent a souligné que la conférence appelait des intervenants et intervenantes de différents horizons à « travailler dans le même sens pour réaliser le changement » [adultes émergents2]. De même, des groupes qui « défendaient des dossiers différents » auraient trouvé « une forte synergie » leur permettant de « tisser des liens et de créer une communauté [. . . ] dont les membres viennent de partout au Canada » et de « promouvoir des initiatives de portée pancanadienne » [adultes émergents1].

\section{Influence prévue sur l'élaboration de politiques}

On a mentionné que la conférence avait préparé les parties prenantes à passer à l'action lorsqu'une ouverture politique se présente en leur fournissant « des données probantes sur les croyances des personnes $œ u v r a n t$ dans ce domaine et sur les occasions qu'elles voient dans un tel changement. Ces données peuvent aussi faire évoluer les politiques publiques » [MJ2]. Toutefois, les recommandations formulées lors de la conférence ont provoqué des sentiments partagés. Un membre du conseil consultatif a trouvé qu'elles étaient « claires et concises » et qu'elles fournissaient des moyens pratiques facilitant leur mise en œuvre qui « interpelleraient différents organismes et des intervenants de tous les secteurs » [CC3]. Un autre a indiqué que « les recommandations étaient basées sur [. . . un grand nombre de solutions et de témoignages » [CC2]. Toutefois, plusieurs participants et participantes ont déploré un manque d'attention accordée aux moyens à mettre en œuvre pour enclencher des changements [MF1, CC2] (Commission de la santé mentale du Canada, 2015a). Selon un membre du conseil consultatif, la conférence a produit non pas des recommandations, mais plutôt un ensemble de lignes directrices : « J'ai l'impression qu'en fin de compte, elles n'ont pas une signification énorme parce qu'elles ne se rattachent pas aux services. Les principes sont bons. Mais ce ne sont pas de véritables recommandations » [CC2].

À l'inverse, un membre du jury a jugé ce format bénéfique, puisque « les provinces, les programmes et les individus seront en mesure de puiser les éléments dont ils besoin [. . . dans les recommandations » en vue de générer des changements à l'échelle locale, provinciale ou nationale [MJ1]. Un autre membre du jury a dit s'attendre à ce que l'énoncé consensuel, ses principes et ses recommandations se répercutent fortement sur le financement et sur les efforts déployés pour augmenter les investissements dans les services aux adultes émergents [MJ3].

Bon nombre de répondants et répondantes croient que la conférence aura pour effet d'améliorer le contenu des politiques, tout en reconnaissant que « modifier des politiques prend du temps » [CC3] et que l'événement incarne « un important jalon sur le chemin vers de meilleures connaissances », un processus qui nécessitera la participation continue d'un grand nombre de personnes pendant plusieurs années encore 
[MJ2]. Certains répondants et répondantes ont aussi mentionné l'intervention de facteurs contextuels déterminants, comme la présence et l'influence de champions du changement [adultes émergents1] au sein d'organisations « ouvertes à ces voix [ . . . et à ces commentaires » [CC3]. Toutes les organisations n'étaient pas considérées comme prêtes à instaurer des changements [MJ1FS]. On a aussi réclamé l'intervention des dirigeants régionaux et nationaux pour favoriser des améliorations durables [DG1] ainsi que l'adoption d'une vision commune à l'échelle du pays afin que les jeunes ne vivent pas d'écarts majeurs dans la qualité des services qu'ils reçoivent lorsqu'ils déménagent dans une nouvelle collectivité [MJ3].

Les répondants et répondantes ont attribué à leur participation à la conférence un nombre étonnant de mesures prises dans les 9 mois qui ont passé depuis l'événement. De nombreux fournisseurs et fournisseuses de services et adultes émergents ont continué à tisser des liens avec d'autres participants et participantes, à apprendre les uns des autres et à s'offrir un soutien mutuel, et ce, " même si une grande distance géographique nous sépare les uns des autres » [adultes émergents2]. D’autres participants et participantes ont dit avoir redoublé d'efforts pour promouvoir cet enjeu, multiplié les conférences et travaillé à des initiatives nationales en collaboration avec divers intervenants [CC3]. Un adulte émergent a mentionné avoir assisté à davantage de réunions intersectorielles depuis qu'il avait appris, grâce aux discussions menées lors de la conférence, l'importance de connaître plusieurs points de vue :

L'une des choses que j'ai apprises à la conférence consensuelle est la nécessité pour les adultes émergents d'être entendus aux tables de décisions où tant de représentants de différents secteurs sont rassemblés.

[adultes émergents2]

Parmi les autres mesures prises depuis la conférence, on a notamment : insisté pour que des adultes émergents siègent dans les groupes de planification [DG2]; transmis des recommandations pour l'intégration de services de politiques à différents gouvernements provinciaux [CC3]; et incité des organisations à faire passer l'âge de transition de 18 à 24 ans afin d'améliorer la préparation des adultes émergents à cette transition [MV1FS]. Les notes de compte rendu et les réponses au sondage font état de la nécessité de s'éloigner du système axé sur l'âge des clients et clientes (Commission de la santé mentale du Canada, 2015a).

\section{DISCUSSION}

S'il est encore trop tôt pour faire une évaluation officielle des effets de la conférence sur l'élaboration des politiques de santé mentale au Canada, les résultats de cette étude de cas montrent que grâce à l'utilisation des données probantes appropriées, à la bonne composition du groupe de participants et participantes et aux ajustements novateurs apportés au format de la conférence consensuelle pour l'adapter à la population et à la réalité des adultes émergents, cet événement de la CSMC a renforcé les capacités des délégués à améliorer les politiques et les pratiques en matière de santé mentale. Les répondants et répondantes ont dit se sentir plus aptes à incorporer les apprentissages effectués lors de la conférence dans leurs activités ultérieures et ont constaté les premiers signes d'une influence exercée sur les politiques de leur organisation.

Les répondants et répondantes ont signalé que leur capacité accrue à comprendre des processus politiques complexes leur avait permis de multiplier les efforts de sensibilisation (Gauvin, 2014; Howlett et al., 2009; Walt et al., 2008) et qu'ils avaient appris des notions nouvelles sur l'âge adulte émergent pouvant faciliter la définition de problèmes et de solutions politiques potentielles (Campbell, 2002; Stone, 2001) et 
contribuer à établir l'ordre des priorités d'action. La conférence a également ouvert les esprits quant à la manière de mobiliser les adultes émergents autour de la planification et de la prise de décisions à l'échelle locale. Les relations qui y ont été nouées ont contribué à raffermir les communautés et les réseaux politiques (Howlett et al., 2009; Sabatier, 1999), et les répondants et répondantes s'attendaient à ce que la publication de l'énoncé consensuel fasse progresser le dossier de la santé mentale des adultes émergents au sein d'un vaste éventail d'organisations, et non seulement dans le domaine des soins de santé mentale.

Tous ces éléments auront permis à la conférence de promouvoir à la fois des intérêts et des idées dans le contexte des institutions canadiennes, faisant en sorte de soutenir la création de solutions politiques en fonction du cadre des « trois i » (intérêts, institutions, idées) d'élaboration de politiques (Gauvin, 2014; Walt et al., 2008). Du même coup, en faisant la lumière sur la problématique de la santé mentale des adultes émergents, la conférence a contribué à rendre le contexte politique plus favorable à l'ajout de ce dossier aux calendriers politiques. Elle a contribué à une définition plus cohérente des problèmes politiques par les différents intervenants et intervenantes, ce qui peut favoriser une formulation de solutions plus éloquentes (Houston et Richardson, 2000). En associant un problème politique reconnu aux solutions proposées et à la mobilisation politique, la CSMC, à titre d'instigatrice de la conférence, pourrait jouer le rôle d' " entrepreneur politique » et créer une ouverture politique afin d'inscrire le dossier de la santé mentale des adultes émergents à l'ordre du jour décisionnel des gouvernements, conformément au modèle des « trois domaines » utilisé pour l'établissement des programmes (Kingdon, 1995). Tandis que certains répondants et répondantes craignaient que les recommandations de la conférence soient trop larges, d'autres y voyaient des principes de haut niveau faisant partie d'une stratégie inclusive étant donné le nombre élevé d'individus et d'organisations susceptibles de contribuer au dossier à plusieurs différents niveaux de politiques et de pratiques dans le contexte institutionnel canadien.

Si ces résultats semblent prometteurs en ce qui concerne les effets à long terme sur l'élaboration de politiques, ils révèlent également des moyens d'améliorer les conférences consensuelles comme mécanisme d'échange de connaissances sur les politiques de santé mentale au Canada, tel que résumé dans la deuxième colonne du tableau 2. Quelques répondants et répondantes ont mentionné qu'il aurait été possible d'accueillir une plus grande diversité de participants et participantes afin d'entendre de nouvelles voix provenant d'autres secteurs et de maximiser l'engagement des populations de PNIM.

En outre, si les services de santé, de santé mentale et de santé au niveau postsecondaire étaient bien représentés, ce n'était pas le cas de certains autres secteurs (justice, système d'éducation secondaire et protection de l'enfance). La CSMC a invité un échantillon représentatif de ces secteurs à partir de sa propre banque de données et a effectué des recherches sur le terrain pour cibler des intervenants et intervenantes là où des lacunes avaient été décelées; il est toutefois possible que les frais de déplacement et d'inscription aient rebuté certains petits organismes ou certaines agences de première ligne ne disposant pas d'un budget d'administration ou de recherche pour couvrir ces coûts. La CSMC a limité l'admissibilité aux subventions disponibles aux participants et participantes ayant vécu la maladie mentale ainsi qu'aux familles et aux proches aidants. Pour rejoindre davantage de participants et participantes, elle pourrait étendre son programme de subventions aux petits organismes ou faire appel aux technologies de vidéoconférence ou de webinaire. Cette dernière option a été envisagée, mais rejetée à la phase de planification en raison de son coût et de la concurrence qu'elle ferait à la participation en personne. 
D'autres répondants et répondantes estimaient que la contribution des adultes émergents aurait pu être facilitée et mieux soutenue et que ces participants et participantes auraient dû jouer un rôle accru dans l'ébauche de l'énoncé consensuel. Bien que la conférence ait fait de grands efforts pour accommoder et fortement favoriser l'inclusion des personnes ayant vécu la maladie mentale, l'expérience avec les adultes émergents n'était pas à point. Parmi ces mesures, notons le statut particulier du panel de sept adultes émergents, l'allocution d'ouverture prononcée par un adulte émergent, la présence d'adultes émergents dans l'auditoire et l'indemnisation de tous les frais engagés par les adultes émergents. En outre, les membres du jury touchaient de modestes honoraires. La voix des jeunes aurait pu être renforcée si tous les groupes de discussion avaient compté au moins un jeune (la plupart des groupes en comptaient un, mais pas tous) et si les jeunes avaient eu l'occasion de se réunir à quelques reprises. De plus, tandis qu'une expertise clinique et une salle privée étaient disponibles sur place, les adultes émergents auraient eu besoin d'un plus grand soutien. Pour l'avenir, il serait notamment possible d'assurer la présence d'un clinicien ou d'une clinicienne (jeune, de préférence) lors de rencontres incluant des adultes émergents.

Des membres de la famille d'adultes émergents étaient présents à la plupart des tables, mais les familles s'inquiétaient néanmoins de leur capacité à faire entendre leur point de vue. En particulier, certains points soulevés par des adultes émergents et des membres des familles ont fait l'objet de désaccords, ce qui a parfois causé de la détresse. Après la conférence, le personnel de la CSMC a discuté avec quelques organisations de familles et avec les membres de familles faisant partie du jury pour trouver des pistes d'amélioration. On a conclu que dans certains cas, il serait plus efficace de permettre aux jeunes et aux membres des familles de se réunir d'abord entre eux pour faciliter leur contribution aux séances plénières.

Enfin, toute conférence tenue sur invitation seulement risque d'avoir des biais de représentation inhérents. Le premier biais provient de la base de données de l'organisation, qui est rarement réellement représentative. Par exemple, si la CSMC a constitué un échantillon représentatif des personnes contenues dans sa banque de données afin de refléter l'éventail de parties prenantes dont les voix doivent être entendues, ce répertoire comporte probablement un nombre biaisé d'organismes et d'individus qui appuient les initiatives de la CSMC et d'intervenantes et intervenants ciblés par la CMSC dans ses efforts de sensibilisation. Ainsi, comme la CSMC compte peu d'initiatives destinées aux membres des Premières nations, aux Inuits et aux Métis (PNIM), les communautés autochtones sont relativement peu représentées dans sa banque de données. En deuxième lieu, le processus de sélection n'était pas totalement aléatoire, de sorte qu'un biais individuel pourrait avoir été introduit avec la préférence d'une personne à une autre. Une combinaison d'échantillonnage aléatoire, d'une meilleure publicisation de la conférence et d'une offre élargie de subventions ciblées pourrait corriger ce biais.

Sur le plan de la planification, malgré les efforts considérables consentis à la préparation de l'événement, plusieurs activités additionnelles potentiellement utiles ont été suggérées. On a proposé, par exemple, de réunir le jury, le conseil consultatif et les adultes émergents innovateurs pour qu'ils apprennent à se connaître avant l'événement; de mieux préparer les délégués et déléguées pour leur permettre de faire des interventions plus significatives; de travailler avec les conférenciers et conférencières pour rendre leur présentation accessible à tous les publics; et de soumettre au jury du matériel élaboré au préalable afin qu'il puisse concentrer ses efforts à peaufiner l'énoncé consensuel. 
En dépit de ces améliorations à apporter, si, comme le croient Lomas et Brown (2009), l'influence d'une conférence consensuelle sur les politiques atteint possiblement son apogée avec la proposition de nouvelles notions et façons de penser, la conférence semble avoir déjà eu des retombées considérables si l'on en croit les commentaires formulés par les répondants et répondantes dans cette étude de cas. L'événement pourrait laisser d'autres legs - comme une meilleure sensibilisation (Kosecoff et al., 1987) aux données probantes sur l'âge adulte émergent, une étape de la vie qui nécessite davantage d'attention du point de vue de la santé mentale, ainsi que l'adoption d'approches participatives à l'égard de l'élaboration de politiques (Nielsen et al., 2006) - qui peuvent avoir une importance certaine dans le contexte des politiques de santé du Canada. D'un point de vue pratique, les effets à long terme de la conférence dépendront de la présence de champions et de leaders du changement ainsi que de la réceptivité des organisations à la rétroaction, de leur volonté d'y donner suite et de leur capacité à entreprendre des réformes.

Pour la CSMC, un organisme national qui ne détient pas le mandat de mettre en œuvre lui-même des changements, les mécanismes d'échange des connaissances susceptibles d'agir sur les politiques et les pratiques de manière indirecte au moyen d'une influence exercée sur les individus, les organisations et les systèmes sont de puissants leviers de changement potentiels (Howlett, 1991; Mulvale, Chodos, Bartram, MacKinnon et Abud, 2014). De même, une des limites de cette recherche tient à ce qu'il est impossible de déterminer avec certitude si les mesures rapportées depuis la conférence sont directement attribuables à la tenue de cet événement. Boyko et al. (2012) soutiennent que si diverses formes de dialogues politiques peuvent contribuer à l'élaboration de politiques, l'attribution directe est impossible en raison de la complexité des processus politiques. Une autre limite est qu'il est difficile de recueillir l'ensemble des points de vue des participants et participantes à la conférence au moyen d'un petit échantillon de répondants et répondantes clés. Néanmoins, aucun effort n'a été épargné pour sélectionner un large éventail de points de vue, et la triangulation des données issues des entrevues avec les sondages des participants et participantes et d'autres sources a révélé un degré élevé de cohérence. De plus, la période visée par l'analyse a limité le signalement aux capacités acquises et aux mesures prises à court terme. Des travaux additionnels devront être effectués pour connaître les retombées à moyen et à long terme de la conférence sur les politiques et les pratiques en matière de santé mentale.

\section{CONCLUSION}

Dans son rôle d'instigatrice de la conférence et d'animatrice de la collaboration interjuridictionnelle et intersectorielle, la CSMC a contribué à créer et à mobiliser des données probantes sur un sujet politique complexe au moyen d'une conférence consensuelle. Bien que le plein effet de la conférence ne se fera sentir que dans plusieurs années, cette étude de cas laisse paraître les premiers signes que l'attention particulière accordée au cadre de réunion, à la diversité des participants et participantes et à l'utilisation de données probantes a permis de renforcer les capacités individuelles d'intégration des preuves issues de la conférence aux politiques et aux pratiques. La conférence semble également avoir créé de fortes communautés de promotion de politiques, favorisé une compréhension et un langage communs basés sur les données probantes et permis l'émergence de nouvelles notions et façons d'envisager la question de la santé mentale des adultes émergents qui commencent déjà à façonner le paysage des politiques et des pratiques au Canada. Les innovations qui ont été apportées au format de la conférence consensuelle, comme la délibération prudente et les mécanismes de 
transmission de la rétroaction des délégués au jury, l'intégration directe de personnes ayant vécu la maladie mentale grâce au panel d'adultes émergents innovateurs et la mobilisation de groupes de jeunes des PNIM à la suite de la conférence, valent la peine d'être poursuivies lors de conférences consensuelles futures dans le domaine de la santé mentale au Canada.

\section{NOTES}

1. La conférence était axée sur quatre grands thèmes : (a) définir l'étape de la vie que traversent les adultes émergents; (b) combler l'écart entre les services de santé mentale et de lutte contre les dépendances destinés aux enfants et aux jeunes et ceux qui s'adressent aux adultes; (c) faciliter les transitions d'un réseau de services à un autre; et (d) mettre en place des mécanismes permettant d'améliorer la réactivité du système de santé mentale.

2. L'énoncé consensuel a été achevé seulement en automne 2016, après des mois de consultation entre le jury, les adultes émergents innovateurs et des intervenants et intervenantes membres des Premières nations, Inuits et Métis. Habituellement, l'énoncé est soumis aux délégués le dernier jour d'une conférence consensuelle, avant d'être publié dans sa version définitive dans les semaines ou les mois suivants. La CSMC a adapté cette partie du processus afin d'inclure toutes les voix et de tenir compte de tous les points de vue, particulièrement ceux qui étaient considérés comme sous-représentés à la conférence.

3. Adulte émergent, membre de la famille (MF), fournisseur ou fournisseuse de services (FS), décideur (D)

4. Adulte émergent innovateur (adultes émergents), membre du jury (MJ), membre du conseil consultatif (CC) et déléguée ou délégué général (DG)

5. Justice, éducation, protection de l'enfance et santé mentale

\section{RÉFÉRENCES}

Arnett, J. (2000). Emerging adulthood: A theory of development from the late teens through the twenties. American Psychologist, 55(5), 465-480.

Boyko, J., Lavis, J, Abelson, J, Dobbins, M. et Carter, N. (2012). Deliberative dialogues as a mechanism for knowledge translation and exchange in health systems decision-making. Social Science \& Medicine, 75, 1938-1945.

Campbell, J. L. (2002). Ideas, politics and public policy. Annual Review of Sociology, 28, 21-38. doi:10.1146/annurev. soc.28.110601.141111

Commission de la santé mentale du Canada. (2012). Changer les orientations, changer des vies : stratégie en matière de santé mentale pour le Canada. Calgary, $\mathrm{AB}$ : Auteur.

Commission de la santé mentale du Canada. (2015a). Consensus Conference on the Mental Health of Emerging Adults, November 2015: Collated input from delegates and EA panel on the Consensus Statement. Document interne, Trans. Ottawa, ON : Auteur.

Commission de la santé mentale du Canada. (2015b). Consensus Conference on the Mental Health of Emerging Adults, November 2015: Capture of plenary presentations and audience interactive sessions. Preparé par Ascribe pour la Commission de la santé mentale du Canada, Trans. Ottawa, ON : Auteur.

Commission de la santé mentale du Canada. (2015c). Taking the next step forward: Building a responsive mental health and addictions system for emerging adults. Ottawa, ON : Auteur.

Davidson, S. et Cappelli, M. (2011). We've got growing up to do: Transitioning from child and adolescent mental health services to adult mental health services. Ottawa, ON: Ontario Centre of Excellence for Child and Youth Mental Health.

Di Rezze, B., Nguyen, T., Mulvale, G., Longo, C., Randall, G. et Barr, N. (2016). A scoping review of evaluated interventions addressing developmental transitions for youth with mental health disorders. Child: Care, Health \& Development, 42(2) 176-187. doi:10.1111/cch.12306

Embrett, M., Randall, G. E., Longo, C., Nguyen, T. et Mulvale, G. (2016). Effectiveness of health system services and programs for youth to adult transitions in mental health care: A systematic review of academic literature. Administration and Policy in Mental Health and Mental Health Services Research, 43(2), 259-269. doi:10.1007/ s10488-015-0638-9 
Fink, A., Kosecoff, J., Chassin, M. et Brook, R. (1984). Consensus methods: Characteristics and guidelines for use. American Journal of Public Health, 74(9), 979-983.Gauvin, F.-P. (2014). Comprendre l'élaboration et les choix de politiques d'après le cadre des " trois I : Intérêts, Idées et Institutions. Montréal, QC : Centre de collaboration nationale sur les politiques publiques et la santé. Récupéré de http://www.ccnpps.ca/ docs/2014_ProcPP_3iCadreRef_FR.pdf

Harrison, S. (2001). Policy analysis. Dans N. Fulop, P. Allen, A. Clarke et N. Black (dir.), Studying the organisation and delivery of health services (p. 90-106). Londres, Angleterre : Routledge.

Houston, D. et Richardson, L. (2000). The politics of air bag safety: A competition among problem definitions. Policy Studies Journal, 28(3), 485-501.

Howlett, M. (1991). Policy instruments, policy styles, and policy implementation: National approaches to theories of instrument choice. Policy Studies Journal, 7(2), 1-21.

Howlett, M., Ramesh, M. et Perl, A. (2009). Studying public policy: Policy cycles and policy subsystems. Toronto, ON : Oxford University Press.

Institute of Health Economics. (2016). Consensus Development Conference series. Récupéré de http://www.ihe.ca/ research-programs/knowledge-transfer-dissemination/consensus-development-conference-series

Jacoby, I. (1988). Evidence and consensus. Journal of the American Medical Association, 259(20), 3039.

Kingdon, J. W. (1995). Agendas, alternatives and public policies (2 éd.). New York, NY : Longman.

Kosecoff, J., Kanouse, D. E., Rogers, W. H., McCloskey, L., Monroe Winslow, C. et Brook, R. (1987). Effects of the National Institutes of Health Consensus Development Program on physician practice. Journal of the American Medical Association, 258(19), 2708-2713.

Lavis, J., Boyko, J., Oxman, A., Lewin, S. et Fretheim, A. (2009). SUPPORT Tools for evidence-informed health Policymaking (STP) 14: Organising and using policy dialogues to support evidence-informed policymaking. Health Research Policy and Systems, 7(S1), S14. doi:10.1186/1478-4505-7-S1-S14

Lincoln, Y. et Guba, E. (1985). Naturalistic inquiry. Beverly Hills, CA: Sage.

Lomas, J., Anderson, G., Enkin, M., Vayda, E., Roberts, R. et MacKinnon, B. (1988). The role of evidence in the consensus process: Results from a Canadian consensus exercise. Journal of the American Medical Association, 259(20), 3001-3005. doi:jama.1988.03720200023027

Lomas, J. et Brown, A. D. (2009). Research and advice giving: A functional view of evidence-informed policy advice in a Canadian ministry of health. Millbank Quarterly, 87(4), 903-926.

McGlynn, E., Kosecoff, J. et Brook, R. (1990). Format and conduct of consensus development conferences: A multination comparison. International Journal of Technology Assessment in Health Care, 6(3), 450-469. doi: http:// dx.doi.org/10.1017/S0266462300001045

McGorry, P. (2007). The specialist youth mental health model: Strengthening the weakest link in the public mental health system. Medical Journal of Australia, 187(7), S53-56.

Miles, M. B., Huberman, A. M. et Saldana, J. (2013). Qualitative data analysis: A methods sourcebook (3 ${ }^{\mathrm{e}}$ éd.). Thousand Oaks, CA: Sage.

Mulvale, G., Chodos, H., Bartram, M., MacKinnon, M.-P. et Abud, M. (2014). Engaging civil society through deliberative dialogue to create the first Mental Health Strategy for Canada: Changing Directions, Changing Lives. Social Science \& Medicine, 123, 262-268.

Mulvale, G., Nguyen, T., Miatello, A., Embrett, M., Wakefield, P. et Randall, G. (2016). Lost in transition or translation? Care philosophies and transitions between child and youth and adult mental health services: A systematic review. Journal of Mental Health. doi:http://www.tandfonline.com/doi/full/10.3109/09638237.2015.1124389

Murphy, M. K., Black, N. A., Lamping, D. L., McKee, C.M., Sanderson, C. F., Askham, J. et Marteau, T. (1998). Consensus development methods, and their use in clinical guideline development: A review. Health Technology Assessment, 2(3).

Nielsen, A., Hansen, J., Skorupinski, B., Ingensiep, H-W., Lassen, J. et Sandoe, P. (2006). Consensus conference: Manual. La Haye, Pays-Bas : LEI, onderdeel Wageningen UR.

Sabatier, P. A. (1999). The need for better theories. Dans P. A. Sabatier (dir.), Theories of the policy process (pp. 3-18). Boulder, CO: Westview Press.

Schwandt, T. (2007). Triangulation. Dans The Sage dictionary of qualitative inquiry. Thousand Oaks, CA : Sage. 
Singh, S., Paul, M., Ford, T., Kramer, T., McLaren, S., Hovish, K. [. . .] White, S. (2010). Process, outcome and experience of transition from child to adult mental healthcare: Multiperspective study. British Journal of Psychiatry, 197(4), 305-312.

Stone, D. (2001). Policy paradox: The art of political decision making. New York, NY : Norton.

Walt, G., Shiffman, J., Schneider, H., Murray, S., Brugha, R. et Gilson, L. (2008). "Doing” health policy analysis: Methodological and conceptual reflections and challenges. Health Policy and Planning, 23, 308-317.

Yin, R. (2003). Case study research design and methods ( $3^{\mathrm{e}}$ éd., Vol. 5). Thousand Oaks, CA : Sage. 